\title{
Baby bust in the wake of the COVID-19 pandemic? First results from the new STFF data series
}

Tomáš Sobotka ${ }^{1}$, Aiva Jasilioniene ${ }^{2}$, Ainhoa Alustiza Galarza², Kryštof Zeman ${ }^{3}$, László Németh ${ }^{2}$, and Dmitri Jdanov ${ }^{2}$

\section{Version 24 March 2021}

\section{Authors' affiliation:}

${ }^{1}$ Vienna Institute of Demography (Austrian Academy of Sciences (OeAW)), Wittgenstein Centre for Demography and Global Human Capital (IIASA, OeAW, University of Vienna), Vienna, Austria; email: tomas.sobotka@oeaw.ac.at

\footnotetext{
${ }^{2}$ Max Planck Institute for Demographic Research (MPIDR), Rostock (Germany)

${ }^{3}$ University of Vienna, Wittgenstein Centre for Demography and Global Human Capital (IIASA, OeAW, University of Vienna), Vienna, Austria
}

\begin{abstract}
Past evidence on fertility responses to external shocks, including economic recessions and the outbreaks of infectious diseases, show that people often put their childbearing plans on hold in uncertain times. We study the most recent data on monthly birth trends to analyse the initial fertility responses to the outbreak of the COVID-19 pandemic. Our research, based on new Short-Term Fertility Fluctuations (STFF) data series (https://www.humanfertility.org/cgi-bin/stff.php), embedded in the Human Fertility Database (HFD), shows the initial signs of the expected "birth recession". Monthly number of births in many countries fell sharply between October 2020 and the most recent month observed, often bringing about a clear reversal of the previous trend. Across 17 countries with lower fluctuations in births, the number of births fell on average by $5.1 \%$ in November $2020,6.5 \%$ in December 2020 and 8.9\% in January 2021 when compared with the same month of the previous year. Spain sustained the sharpest drop in the number of births among the analysed countries, with the number of births plummeting by $20 \%$ in December 2020 and January 2021 . The combined effect of rising mortality and falling birth rates is disrupting the balance of births and deaths in many countries, pushing natural population increase to record low levels in 2020 and 2021.
\end{abstract}

\section{Keywords:}

Births, fertility, trends, COVID-19, data, monthly data, short-term fluctuations, highly developed countries, Europe, United States, East Asia, Human Fertility Database 


\section{HIGHLIGHTS}

- This report presents results from the new Short-Term Fertility Fluctuations (STFF) data series (https://www.humanfertility.org/cgi-bin/stff.php), embedded in the Human Fertility Database (HFD).

- The outbreak of COVID-19 was associated with an accelerated decline in the number of births in most of the 22 analysed highly developed countries in November 2020 - January 2021.

- Across 17 countries with lower fluctuations in reported births, the number of births fell on average by $5.1 \%$ in November 2020, 6.5\% in December 2020 and $8.9 \%$ in January 2021 when compared with the same month of the previous year (January 2021 data are available only for nine countries).

- In 15 analysed countries of the European Union, the year-on-year number of births plunged by $3.0 \%$ in October 2020, 5.0\% in November 2020 and 8.1\% in December 2020.

- Similar downturn in births is observed in the United States, with year-on-year decline of $7.7 \%$ in December 2020.

- Births in Russia dropped by $10.3 \%$ in January 2021, whereas births in France were down by 13.5\% in January 2021 when compared with January 2020.

- Spain sustained the sharpest drop in the number of births among the analysed countries: births plummeted by $20.4 \%$ in December 2020 and by $20.0 \%$ in January 2021 .

- There was no country with a sustained trend towards an increase in the number of births, indicating that the COVID-19 pandemic has not led to a baby boom.

- Births in Denmark, Finland, the Netherlands, and Norway remained stable until December 2020 or January 2021, so far unaffected by the COVID-19 pandemic. In Bulgaria, Slovenia, and South Korea, the ongoing decline in the number of births during 2020 has continued without further accelerating in the most recent months.

- The decline in the number of births is likely to accelerate in the first months of 2021, with record-low number of births and Total Fertility Rate expected in many countries in 2021.

- A combination of increasing number of deaths and plunging number of births has negatively affected natural population increase, leading to its sharp downturn in many countries. 


\section{Introduction}

The Coronavirus disease 2019 (COVID-19) pandemic has profoundly affected every aspect of our lives, including family-related behaviours (Settersen et al. 2020). Initially, attention to the demographic costs of the pandemic was concentrated on deaths and excess mortality due to COVID-19. As data on births in late 2020 and early 2021 become available for many countries, it is possible to get a first look at an initial impact of the pandemic on births and fertility trends. Some early media accounts suggested that the lockdowns may lead to a baby boom as couples spend more time together. However, past evidence on fertility responses to external shocks, such as economic crises and financial turbulences (Sobotka et al. 2011; Comolli 2017) as well as on the outbreaks of infectious diseases such as the Zika infection in Latin America (Rangel et al. 2020; Marteleto et al. 2020) show that people often postpone or revise their childbearing plans in uncertain times (Vignoli et al. 2020). These responses result in considerable short-term fluctuations in fertility (e.g., Comolli and Vignoli 2021). Indeed, surveys on fertility intentions in Europe and in the United States during the first wave of the COVID-19 pandemic in Spring 2020 revealed that many women decided to delay or even give up their childbearing plans (Lindberg et al. 2020; Luppi et al. 2020).

Especially in the highly developed countries, where couples have access to reliable birth control and most women are employed, the pandemic is expected to depress fertility rates as many people struggle with economic uncertainty, worries about the health consequences of the pandemic and stress related to lockdowns and restrictions to everyday life (Aassve et al. 2020; Settersen et al. 2020; Kearney and Levine 2020a). The pandemic has also affected reproductive behaviour in more subtle ways: marriages were postponed, younger people and couples not living together had fewer opportunities to meet, some couples reported less frequent sexual intercourse (Lehmiller et al. 2020 for the United States), families struggled to accommodate to home schooling and other needs of their children staying at home, and contact with grandparents-important providers of childcare-was often interrupted for many months. The actual impact of the COVID-19 pandemic on birth trends could not be studied until recently. Considering time needed to get pregnant and the duration of pregnancy, which is close to 9 months from ovulation to delivery (266 days or 8.7 months on average; Jukic et al. 2013), the onset of the pandemic in March 2020 would first affect births in November and December $2020 .^{1}$

In the absence of actual data, Wilde et al. (2020) used data on Google searches for 40 fertility-related keywords to predict short-term trends in the birth rates in the United States in the wake of the pandemic. They projected that births would start dropping in November 2020 and this fall would accelerate until February 2021, with about 15\% fewer births expected compared to October 2020. Outside the United States, media in many countries drew some evidence from hospital records and preliminary, often local and small-sample, datasets, which reported fewer pregnancies and births in the last months of the year. An early evidence mostly supported the notion that the COVID-19 pandemic would bring about a sharp decline in the number of births and pregnancies and the initial speculations about possible baby boom have largely vanished, with many reports of the looming COVID-19 "baby bust" (Pinsker 2020) and "baby crash" in 2021. Among the more systematic efforts to analyse first data on birth trends, Philip N. Cohen (2021) reported a substantial decline in the number

\footnotetext{
${ }^{1}$ This assumption excludes preterm births and the possibility that some women, who were pregnant at the time of the COVID-19 outbreak, might have decided for an abortion in the early stage of the pandemic.
} 
of births in some states of the United States in December 2020, reaching around $10 \%$ in Arizona, California, Ohio and Florida.

Beaujouan (2021) argued that to properly research the impact of COVID-19 pandemic on population trends we need to develop robust, cross-nationally comparative data sets. As first data on births in late 2020 and early 2021 became available, researchers from the Max Planck Institute for Demographic Research (Rostock, Germany) and Vienna Institute of Demography (Austrian Academy of Sciences, Wittgenstein Centre for Demography and Global Human Capital) developed a new data series on trends in monthly number of births, the Short-Term Fertility Fluctuations (STFF) data series (https://www.humanfertility.org/cgi-bin/stff.php), which is incorporated in the Human Fertility Database (2021). This report gives a first overview on birth trends in the highly developed countries covered by the STFF dataset, focusing on countries with available data until at least December 2020. We focus especially on the dynamic of trends in the monthly number of births since October 2020 and at the relative changes in the number of births compared with the same month in the preceding year. Our report first provides a detailed picture of birth trends in East Asia, the United States, and in broader European regions. Then we summarise the available evidence for the highly developed countries. Overall, most of the evidence suggests that recent birth trends have been negatively affected by the COVID-19 pandemic and many countries are likely to see their period fertility rates plummeting to record-low levels in 2021.

\section{Data and methods}

Our report draws from the Short-Term Fertility Fluctuations data series launched on 12 March 2021 and embedded in the Human Fertility Database (HFD) website. The dataset features data on the number of live births per month since January 2000 in highly developed countries with good quality of vital registration data and almost complete coverage of births in their vital statistics. The main purpose of the STFF data is to provide a timely information on the recent monthly trends in the number of births, prior to the publication of more detailed final data on births and fertility rates, which are often published with considerable delay. The STFF dataset is therefore especially suitable for studying birth and fertility fluctuations that arise in response to external shocks - such as an outbreak of the COVID19 pandemic or economic shocks and turbulences-or in response to significant changes in familyrelated policies.

As of 12 March 2021, the STFF data series covers data for 32 countries, most of which has been released and published by national statistical offices. In this report we focus on a subset of these data, covering all countries for which data were available at least until December 2020, when the early impact of the COVID-19 pandemic on births conceived in March 2020 should have become clearly visible. These data include ten countries with the birth data available until December 2020 (Austria, Belgium, Bulgaria, Denmark, Republic of Korea (hereafter South Korea), Latvia, Norway, Romania, Ukraine and the United States), ten countries for which the data are available up until January 2021 (Croatia, Estonia, Finland, France, Hungary, Netherlands, Russia, Slovenia, Spain, and Sweden) and two countries with data reported until February 2021 (Lithuania and Taiwan). Altogether, we cover 19 European countries, two countries in East Asia (South Korea and Taiwan) and the United States (see Appendix 1 for more details on the countries included in the STFF database and those covered in this report).

There are considerable challenges when analysing monthly data on births. The first challenge concerns data quality and definitions. Often, initial data that are reported within a few months are preliminary and are subject to subsequent revisions and adjustments. These adjustments might eventually 
increase the reported number of births in the most recent months, possibly turning what appears as considerable fall in the number of births to a small blip in a few cases. In addition, some countries report monthly birth data by month of registration rather than month of occurrence, which might be an issue in times when data collection and reporting are disrupted, as was often the case during the early stage of the COVID-19 pandemic. As a result, monthly birth data for some countries suffer substantial fluctuations, which might also affect birth numbers reported in the final month of the year, when some of the late-reported births are added to the database. This factor probably explains a sudden and unexpected spike in the number of births in December 2020 reported in some countries with a "suspicious" time-limited sharp fall in the reported births in March-May 2020, including Lithuania, Romania, Russia, Ukraine, and Taiwan (Appendix Figure AP-1). To filter out these fluctuations, we exclude these countries from parts of our comparative analyses. ${ }^{2}$ Although we do not have space to address country-specific data issues here, we strive to provide up-to-date information on data definitions and data quality issues on the HFD website, specifically in the STFF Methodological Note (https://www.humanfertility.org/DOCS/STFFNote.pdf) and in the STFF Metadata file that covers data definitions, data sources and data issues for individual countries (https://www.humanfertility.org/DOCS/STFFmetadata.pdf).

The second challenge of working with monthly data pertains to the seasonality of births. In most countries, births display a seasonal cycle during the year. While this seasonality often changes in time, even contemporary societies with high levels of contraceptive use display a seasonal pattern of conceptions and births (e.g., Régnier-Loilier and Divinagracia 2010; Dahlberg and Andersson, 2019). Without filtering out the effects of seasonality as well as uneven length of calendar months and uneven number of weekdays in different months, monthly birth trends cannot be simply compared between adjacent months as most of these monthly fluctuations might be driven by these effects rather than by genuine changes in reproductive behaviour. To address this issue, our analysis of birth dynamics focuses on relating monthly number of births to the same month in the previous year rather than to the preceding months.

The third issue pertaining to working with absolute numbers is well known to demographers: numbers of births, deaths and other vital events are crude indicators that are not adjusted for the changing size of population in a given country or region and its changing age and sex composition. Therefore, numbers of births may change over time due to such compositional factors that are normally controlled for in the standard demographic indicators, such as the Total Fertility Rate. Therefore, our main focus is on relatively short period of time, during which changes in population size and composition should have a relatively minor impact on the observed number of births.

In particular, our analysis puts a spotlight on changes in birth trends between October 2020-the last month when births were relatively unaffected by the COVID-19 pandemic as most were conceived prior to March 2020-and, depending on data availability, December 2020 to February 2021. Our main indicator of interest is the relative monthly change in the number of births compared to the same month in the previous year and its dynamics in the observed period, including during the whole year 2020. As births often showed dynamic and often declining trajectory during the year 2020, observing a relative decline in the number of births in the most recent period is not sufficient to suggest a negative impact of the COVID-19 pandemic on births. As we show below, some countries, including Lithuania, South Korea and Slovenia, displayed a stable trend of declining number of births throughout the year 2020 and in January 2021, indicating that their downward fertility trend has not yet been driven or accelerated by the pandemic. Therefore, only when the most recent trends are compared

\footnotetext{
${ }^{2}$ In addition, data for two regions, Scotland and Northern Ireland, where births are reported by month of registration, were not even included in the STFF data series as the reported number of births plummeted close to zero during the first wave of the COVID-19 pandemic in April-May 2020.
} 
and contrasted with the "yardstick" of the birth trends prior to November 2020, it is possible to assess an impact of the COVID-19 pandemic on births.

\section{Different birth trends across countries and regions}

As we show below, birth "responses" to the COVID-19 pandemic differed widely across countries. Often, countries in broader geographical regions displayed similar shifts and trends in time. This section analyses data by broader regions, looking at the changes in East Asia, the United States, Western Europe, Nordic countries, Southern Europe, Central Europe, Eastern Europe and SouthEastern Europe. We provide illustrations of birth trends in selected countries, with Appendix figures giving more detailed evidence for many countries. Key findings are then summarised in the next section.

\subsection{East Asia}

Birth data for South Korea and Taiwan depict a continuing downward trend throughout 2020. In South Korea, this shift is a continuation of a long-standing fertility decline towards extreme low levels, which until December 2020 does not appear to be further accelerated by the COVID-19 pandemic (Figure AP2 in Appendix and Figure 2). ${ }^{3}$ By contrast, data for Taiwan, which are available until February 2021, show a steep fall in relative birth numbers in January-February 2021 peaking at $23 \%$ in January (Figure 1). Despite huge fluctuations in Taiwanese monthly birth data (Figure 2), this gives a signal of an accelerated birth decline following the COVID-19 outbreak. Data for Japan are not yet available for the whole year, but media reports based on pregnancies reported to local health authorities expect a downward trend in the number of births (Ryall, 2020).

\footnotetext{
${ }^{3}$ According to preliminary data the Total Fertility Rate in South Korea plunged to 0.84 birth per woman (Statistics Korea, 2021), the record-low level in the country and the lowest level globally in 2020.
} 
Figure 1: Recent trends in the number of births by month in Taiwan and relative change in the number of births compared to the same period in the preceding year

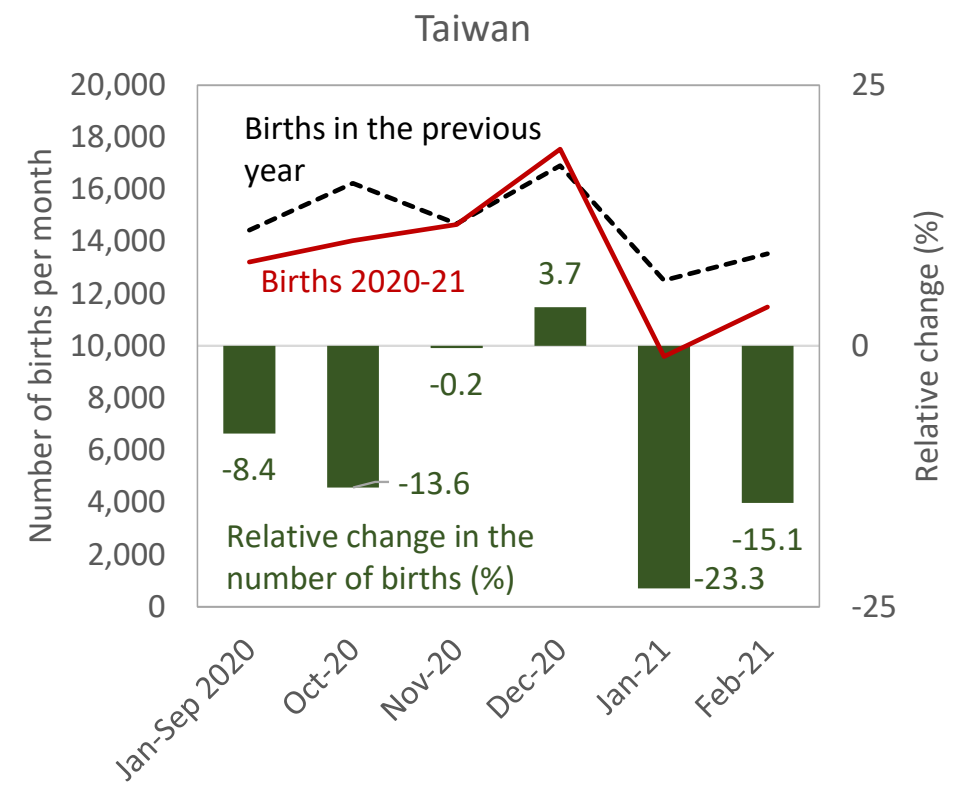

Figure 2: Relative change (\%) in the number of births since January 2020 compared with the same month in the preceding year; South Korea and Taiwan compared with the average for 17 countries
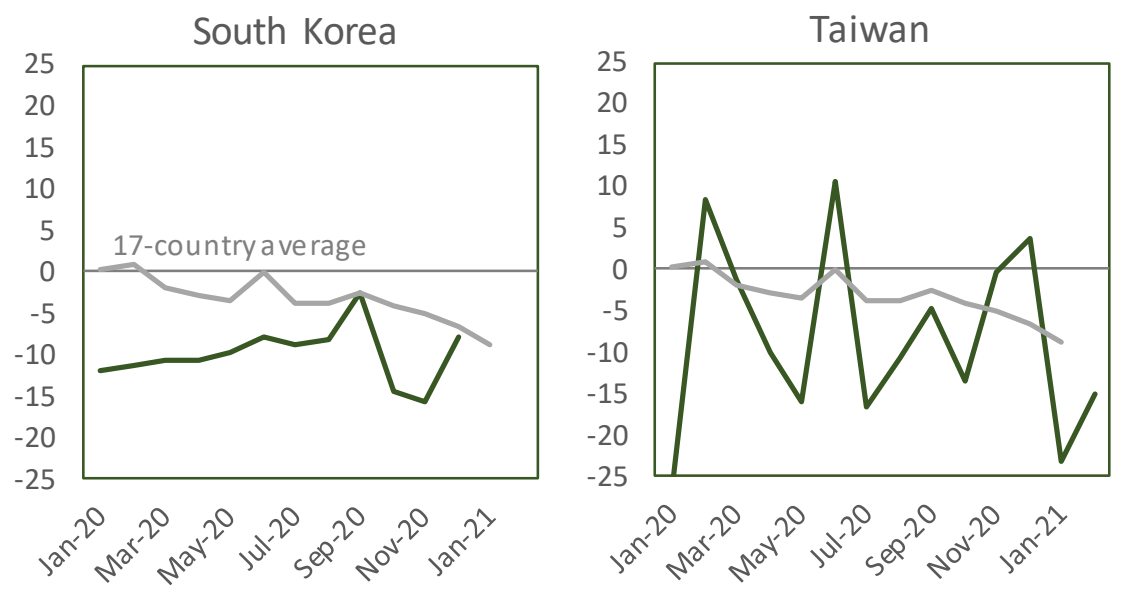

Note: The 17-country average includes the following countries: Austria, Belgium, Bulgaria, Croatia, Denmark, Estonia, Finland, France, Hungary, Latvia, the Netherlands, Norway, South Korea, Slovenia, Spain, Sweden, and the United States. Five countries with unstable monthly data and a peak in December 2020 were excluded (Lithuania, Romania, Russia, Taiwan and Ukraine).

\subsection{United States}

Multiple sources of data and information-including surveys of reproductive preferences (Lindberg et al. 2020), surveys on sex lives (Lehmiller et al. 2020), data based on Google searches (Wilde et al. 2020), initial evidence from selected states (Cohen 2021), diverse media accounts (Pinsker 2020), and expert predictions (Kearney and Levine 2020)-all pointed in one direction: an expected downturn in births in the United States resulting from the COVID-19 pandemic. Preliminary vital statistics data, available for the period through December 2020, broadly conform this expectation: number of births has been declining in late 2020 and this decline has been sharpest when compared with the 2019 figures (by 
7.7\%) in December 2020. This is in line with the predictions by Wilde et al. (2020). The only unexpected feature of the birth decline in the United States is that it has been building up gradually throughout the spring and summer months, i.e., before the COVID-19 pandemic could have impacted pregnancies and births (Figure 3a). At the same time, the birth trend in the US followed relatively closely the average trajectory of birth decline across 17 analysed countries (Figure 3b). If the expected future impact of the COVID-19 materializes, US births will fall yet much deeper in the first months of 2021.

Figure 3a: Trends in the number of births by month in 2020 and relative change in the number of births compared to the same month in 2019, United States (left panel)

Figure 3b: Relative change (\%) in the number of births since January 2020 compared with the same month in the preceding year; United States and the average for 17 countries (right panel)



Note: See Figure 2 for the list of countries included in the 17-country average.

\subsection{Western Europe}

Except in the Netherlands, data on birth trends in three Western European countries-Austria, Belgium and France-are broadly in line with the trajectory of births in the United States and with an average trend across all analysed countries, showing an accelerated decline in the final months of 2020 (Austria, Belgium), which is further continuing in January 2021 (France). In these three countries, births were down by 5.5\% (Austria) to 7\% (Belgium and France) in December 2020 when compared with December 2019 and this fall deepened to $13.5 \%$ in France in January 2021 when compared with January 2020 (Figures 4-6, Appendix Figure AP-3).

By contrast, data for the Netherlands show a stable level of births throughout 2020 and in January 2021, so far uninterrupted by the pandemic (Figure 6, Appendix Figure AP-3). This puts the country's experience close to that of several Nordic countries, which-with the exception of Sweden-did not see any obvious pandemic baby bust until December 2020 or even January 2021 (see below). Possibly, 
a yet sharper downturn in births might occur in Switzerland, where data available until November 2020 show a year-on-year fall in the number of births by $13.8 \%$ in that month (Appendix Table AP-2).

Figure 4: Trends in the number of births by month in 2020 and relative change in the number of births compared to the same month in 2019, Belgium

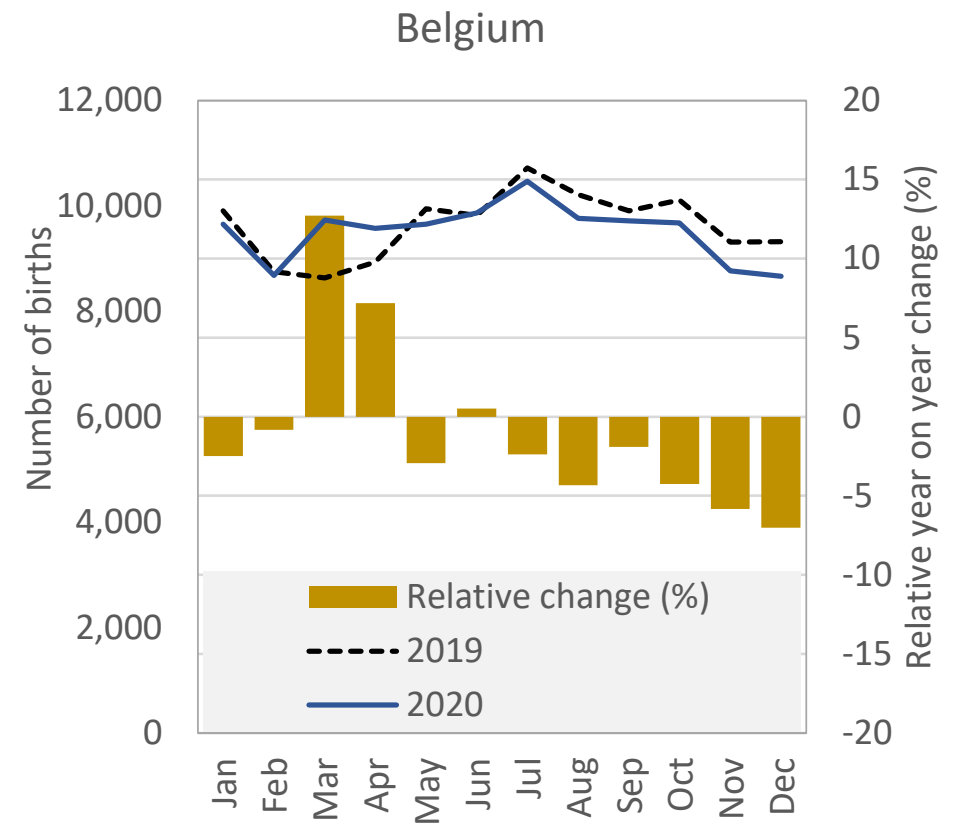

Figure 5: Recent trends in the number of births by month in France and relative change in the number of births compared to the same period in the preceding year

France

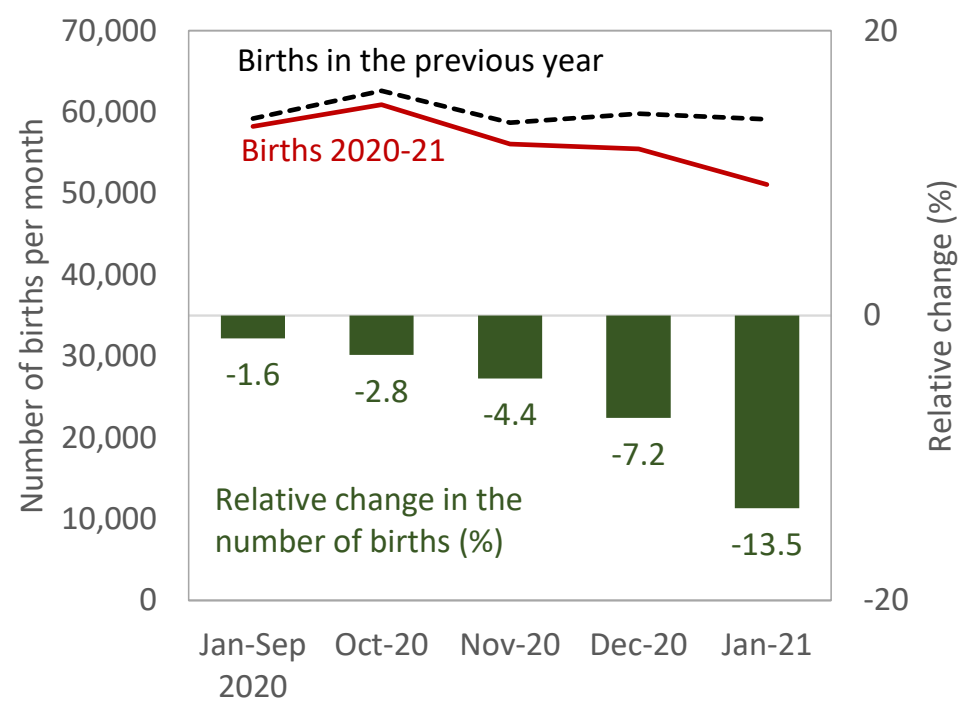


Figure 6: Relative change (\%) in the number of births since January 2020 compared with the same month in the preceding year and with the average for 17 countries; Western Europe
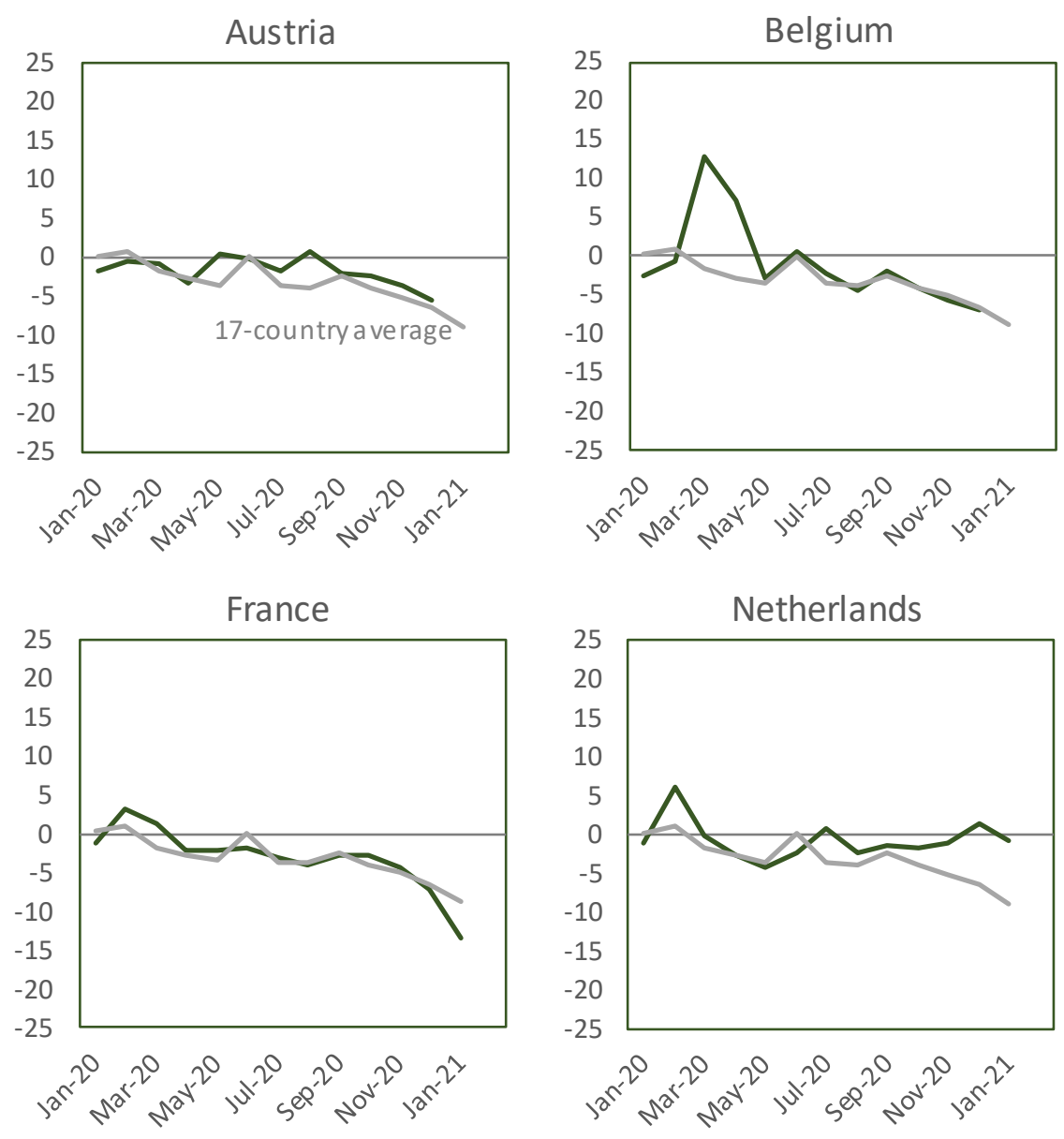

Note: See Figure 2 for the list of countries included in the 17-country average.

\subsection{Nordic countries}

In contrast to most of the Western European countries, Nordic countries have not recorded steep falls in the number of births so far and the broader picture for the region seems to suggest no impact of COVID-19 on fertility trends in the initial months until December (Figure 8). Two countries, Finland and Sweden reported data until January 2021. Finland shows a continuation of a stable trend of a slight increase in the number of births compared with the same period in the previous year, whereas Sweden displays a clear downturn in births (-6.4\%) starting in January (Figure 7). Denmark and Norway display no clear trend until December, when both show a small uptick in the number of births compared with December 2020 (Appendix Figure AP-2). 
Figure 7: Recent trends in the number of births by month in Finland and Sweden and relative change in the number of births compared to the same period in the preceding year

Finland

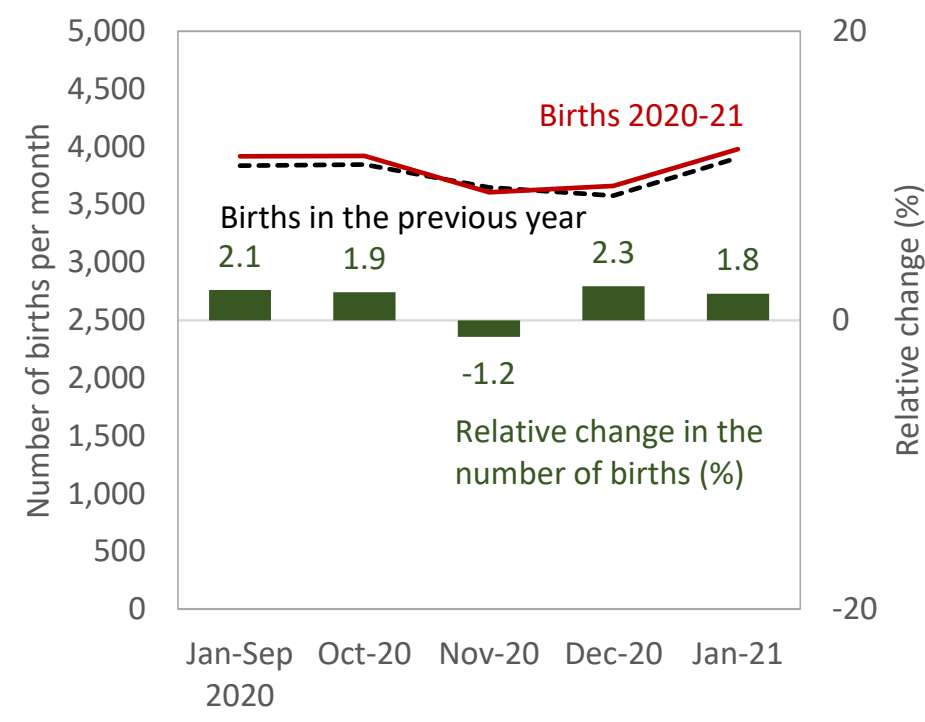

Sweden




Figure 8: Relative change (\%) in the number of births since January 2020 compared with the same month in the preceding year and with the average for 17 countries; Nordic countries


Note: See Figure 2 for the list of countries included in the 17-country average.

\subsection{Southern Europe}

The only Southern European country for which the birth data are currently available until at least December 2020 is Spain. Preliminary birth trends in Spain until January 2021 reflect most closely the idea of a sudden shock, a "baby crash" in response to the onset of the COVID-19 pandemic, which hit the country hard during its first wave in Spring. It further worsened the relatively challenging economic and social conditions for childbearing and parenthood in the country (Adserà 2011; Barbieri et al. 2015). Compared with the same month in the previous year, the number of births fell by $6 \%$ in October 2020 , by $11 \%$ in November, and then plummeted by $20.4 \%$ in December 2020 and by $20.0 \%$ in January 2021 (Figures 9a and 9b), the sharpest decline among the analysed countries (see also Figure 17 below). As a result of this sharp downturn in late 2020, births in the whole year 2020 fell by almost $10 \%$ and yet a steeper fall is likely to take place over the whole year 2021. An early evidence for Italy suggests a similar sharp fall in births: in November 2020 (the latest available data), the number of births was down by $8 \%$, showing a clear acceleration compared with the previous months. Preliminary data on births in 15 large Italian cities, comprising over $10 \%$ of the population in the country, show a fall in the number of births by $8.2 \%$ in November (identical as the data for the whole country), accelerating to $21.6 \%$ in December-almost the same value as in Spain (Blangiardo 2021). 
Figure 9a: Recent trends the absolute number of births by month in Spain and relative change in the number of births compared to the same period in the preceding year (left panel)

Figure 9b: Relative change (\%) in the number of births since January 2020 compared with the same month in the preceding year; Spain and the average for 17 countries (right panel)

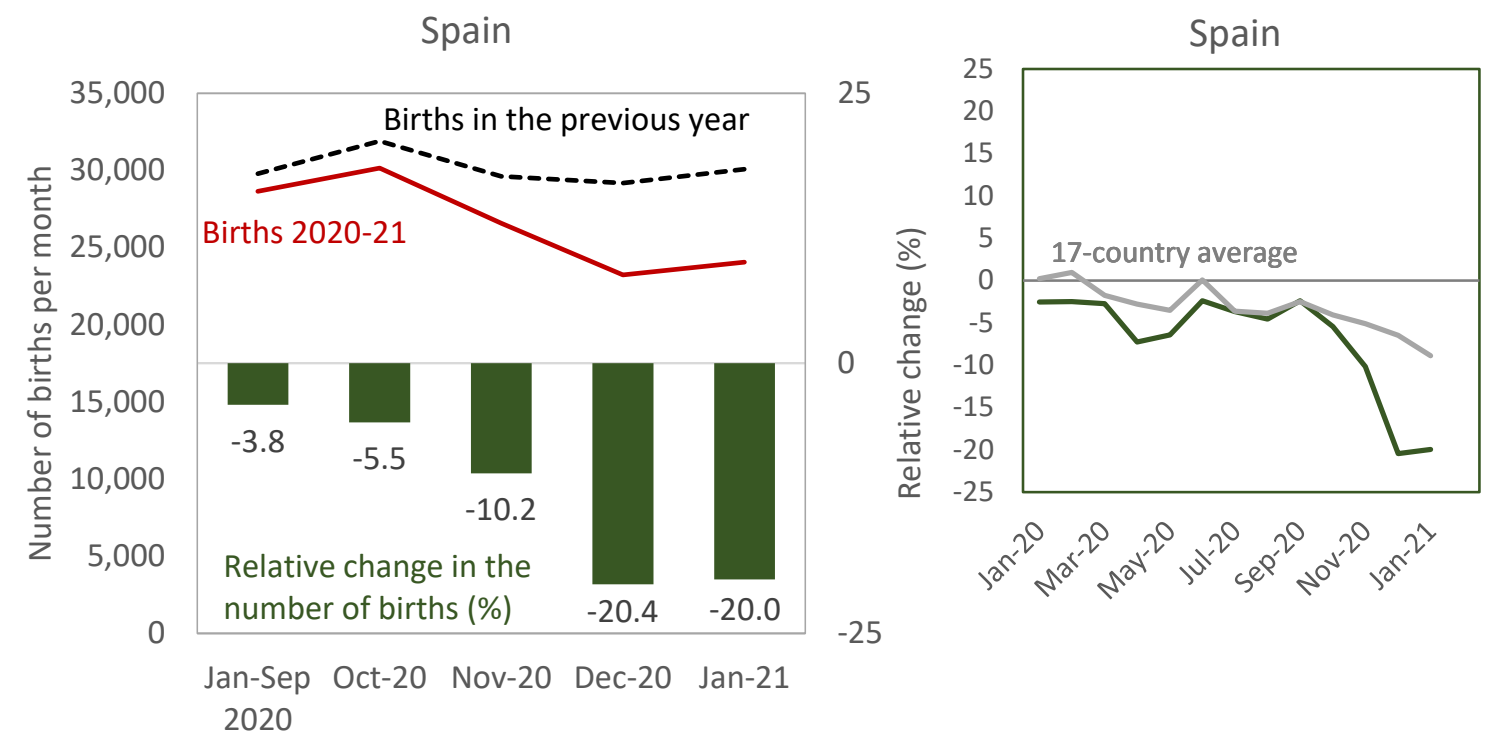

Note: See Figure 2 for the list of countries included in the 17-country average.

\subsection{Central Europe}

We cover Central European countries together with the Baltic countries. Birth data for some of these countries suffer considerable fluctuations, which introduce additional "noise" into the time series and make the trends over time more difficult to interpret. Birth data for the three Baltic countries, Estonia, Latvia and Lithuania, as well as the data for Croatia, have displayed much higher instability than the data for most other countries (Figure 11), with the exception of Taiwan and the countries of Eastern and South-eastern Europe discussed below.

However, in most of the analysed countries, births have been falling after October 2020. The trend reversal is most obvious in Hungary, where the number of births had been rising until November 2020, possibly propelled in part by extensive pronatalist policies in the country (Makay 2019). The "surplus" of births quickly melted away after October 2020 , with the relative increase of $+3 \%$ in October falling over the next three months and reaching -9.8\% in January 2021 (Figures 10 and 11). Data for Estonia suggest that, despite fluctuations, birth trends turned sharply negative in December 2020 and January 2021 , falling by $15 \%$ and $17 \%$, respectively, when compared with the same month in the previous year (Figure 10). Data for Croatia (Appendix Figure AP-3) and Latvia (Appendix Figure AP-2) also appear to be heading downwards in December 2020 and January 2021 (only Croatian data available), but given their fluctuations, only the data for more recent months will provide a more solid evidence to confirm the downturn. By contrast, data for Slovenia (Figure AP-3) show that after a sharp drop in November 2020, births in December 2020 and January 2021 were falling by a similar pace as over most of the year 2020, suggesting that the pandemic has not sped up the established trend. Recent Lithuanian data also do not display any downward trend; the sharp upturn in December was probably due to delayed registration of births that took place during the first wave of the COVID-19 pandemic in Spring 2020, when a notable dip in the number of reported births is apparent in the data (Figure 11). 
Figure 10: Recent trends in the number of births by month in Estonia and Hungary and relative change in the number of births compared to the same period in the preceding year
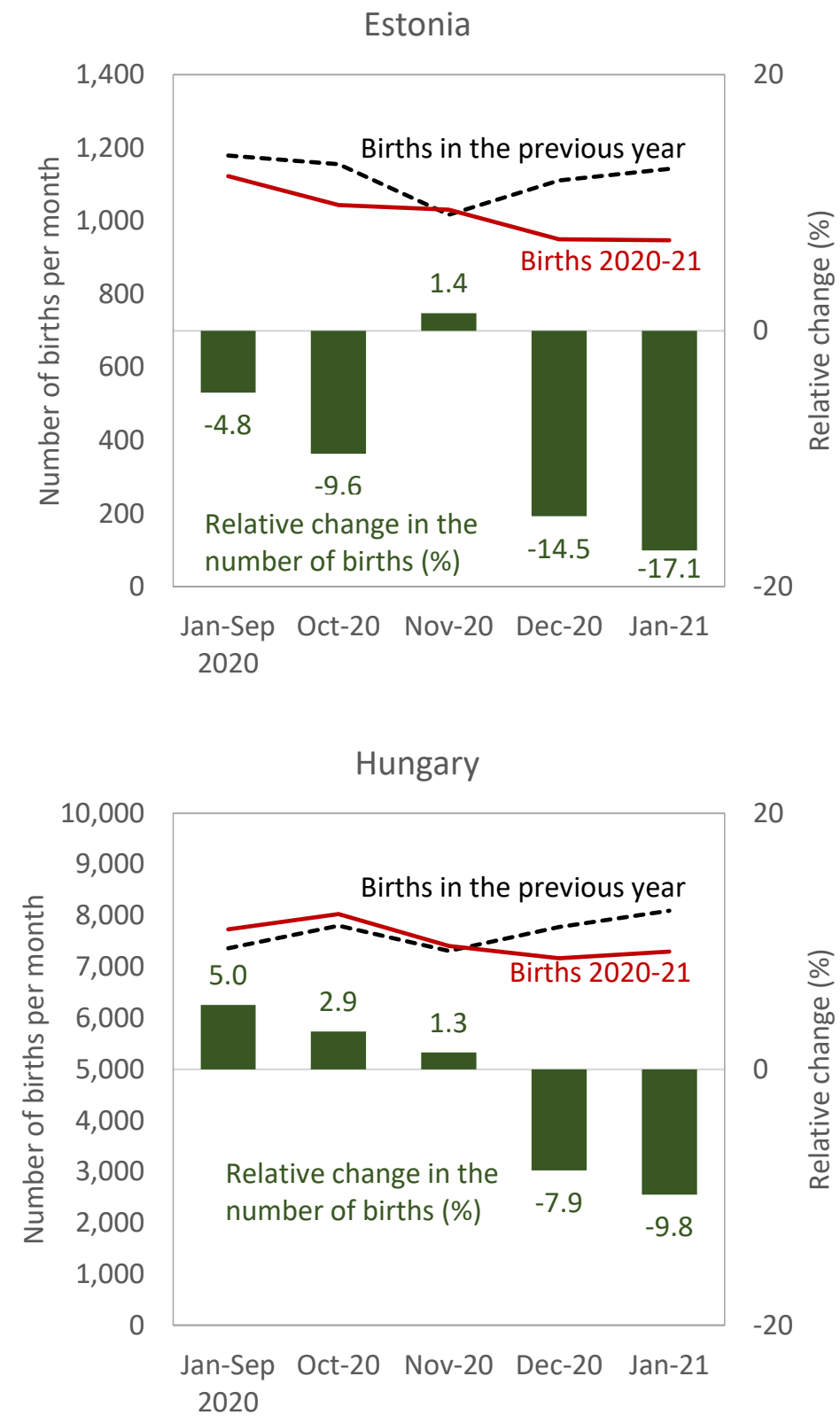
Figure 11: Relative change (\%) in the number of births since January 2020 compared with the same month in the preceding year and with the average for 17 countries; Central European countries
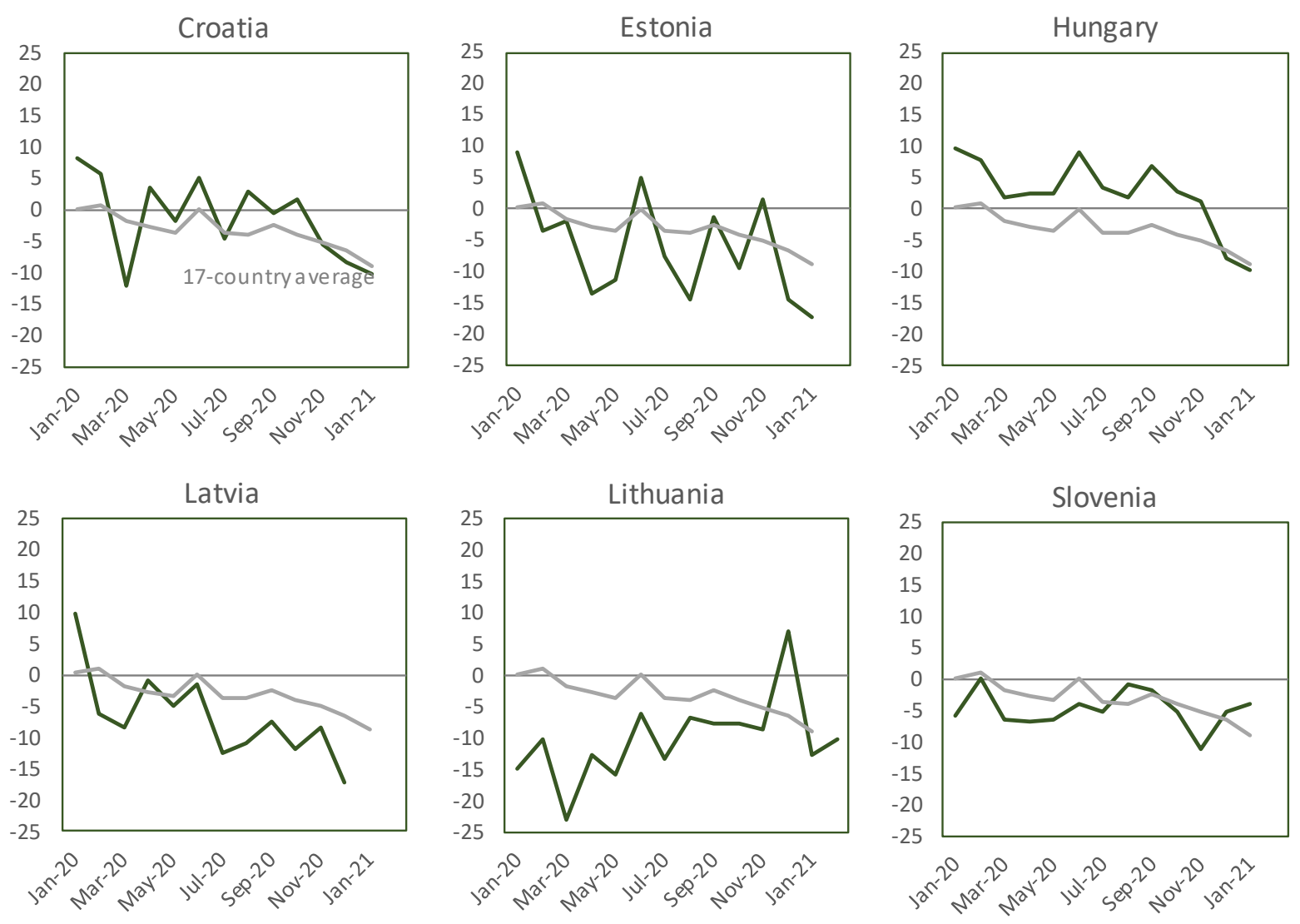

Note: See Figure 2 for the list of countries included in the 17-country average.

\subsection{Eastern and South-Eastern Europe}

Among the four analysed countries, Bulgaria, Romania, Russia and Ukraine, the latter three suffer from sharp fluctuations in the reported number of monthly births (Figure 13), similar to Lithuania and several other countries in Central Europe discussed above. The peculiar pattern of seemingly recovering birth trends in Romania is likely caused by a late registration of births that were "missing" in Spring 2020, when the number of registered births plummeted by $21 \%-27 \%$ for four successive months, from February to May (Appendix Figure AP-2). Similarly, the sharp peaks in births in Russia and Ukraine in December 2020 (Figures 12 and 13) are probably linked to delayed reporting of births that took place earlier in the year. Regional data for Russia indicate that the December peak has been unevenly distributed across the country and that especially more remote and peripheral regions reported the largest uptick in births; these include Far East region (+16\%) and Northern Caucasus region (+27\%) (Rosstat 2021).

Only the data for Bulgaria display more stable pattern over the year 2020, with no change in the pace of relative decline in the number of births in October-December 2020 (Appendix Figure AP-2). Among the other three countries, only the data for Russia are available for January 2021, when births fell by over 10\% compared with January 2020 (Figure 12), the largest year-on-year fall since Summer 2019. This indicates that fertility trends in Russia have been negatively affected by the COVID-19 pandemic, but only the data for the subsequent months will show, whether this trend continues. 
Figure 12: Recent trends in the number of births by month in Russia and relative change in the number of births compared to the same period in the preceding year

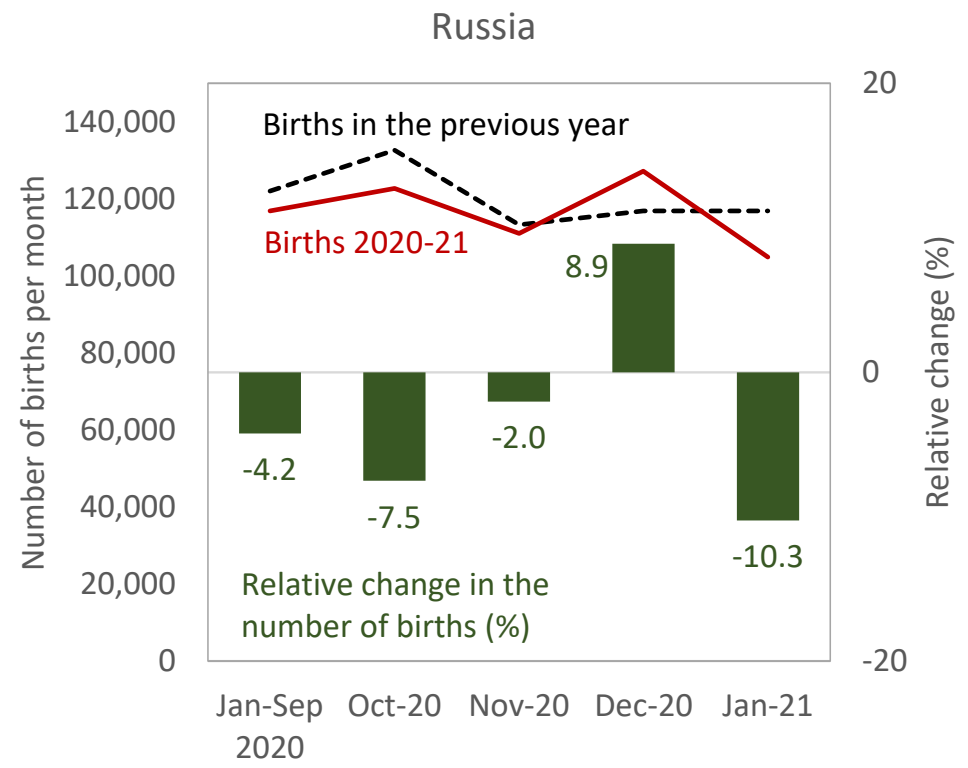

Figure 13: Relative change (\%) in the number of births since January 2020 compared with the same month in the preceding year and with the average for 17 countries; Eastern and South-Eastern Europe
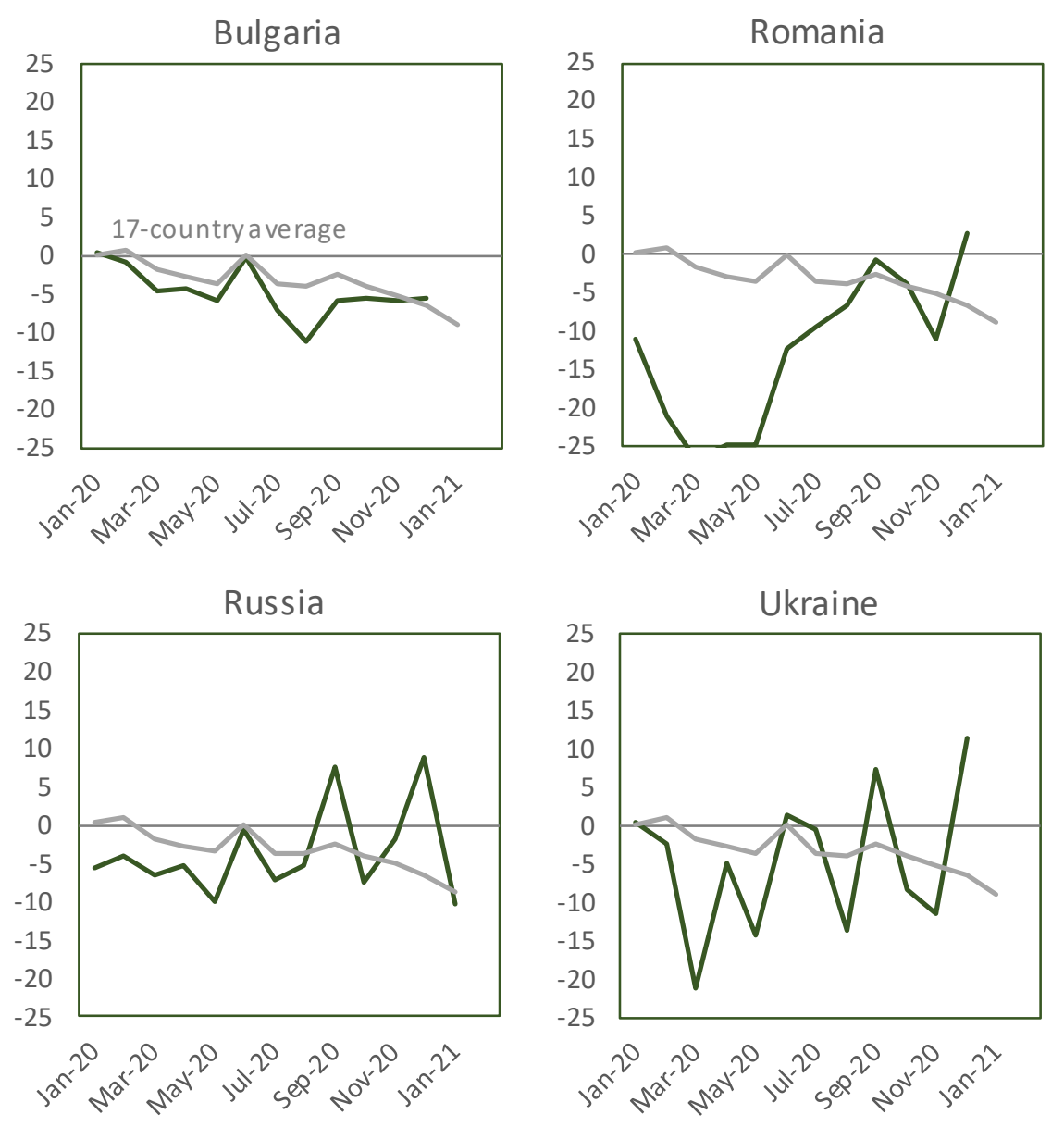


\section{The emerging negative impact of the COVID-19 pandemic on birth trends: a summary}

Our analysis of recent birth trends revealed considerable diversity between countries and regions. In this section we summarise main findings across countries. First, we provide a summary picture of birth trends across 17 countries, excluding those with high volatility in monthly births, especially in the most recent period, including December 2020. Next, we summarise the evidence on regional and crosscountry differences. Then we provide additional analysis of most recent birth trends in the subset of countries with the data available for January 2021.

\subsection{Birth trends since January 2020}

Figure 14 summarizes births trends from January 2020 until January 2021 across the analysed countries, excluding five countries with unstable trends and with a spike in births reported in December 2020. The average trend in relative year-on-year change in the number of births shows an expected downturn after October 2020, first gradual and accelerating only in January 2021 (when data for fewer countries are available). On average, births fell by $5.1 \%$ in October 2020 , by $6.5 \%$ in December 2020 and by $8.9 \%$ in January 2021 . $^{4}$ The change from October to December 2020 , while fitting the expected trend, is not unusual when compared with the birth trends earlier in 2020. It is only in January 2021 when the birth decline appears to accelerate, with widening differences across countries: some countries like Estonia, Spain and Taiwan see their birth rates plunge, while other countries like Finland and the Netherlands do not show any significant change in birth trends.

\footnotetext{
${ }^{4}$ The shift from December 2020 to January 2021 is not affected by the smaller number of countries covered in January 2021: it remains almost identical, from $-6.7 \%$ to $-8.9 \%$, when the average values for December 2020 are computed only for these nine countries.
} 
Figure 14: Average change in the number of births compared with the same month in the previous year and cross-country differences in year-on-year birth trends: evidence for 17 countries, January 2020 to January 2021

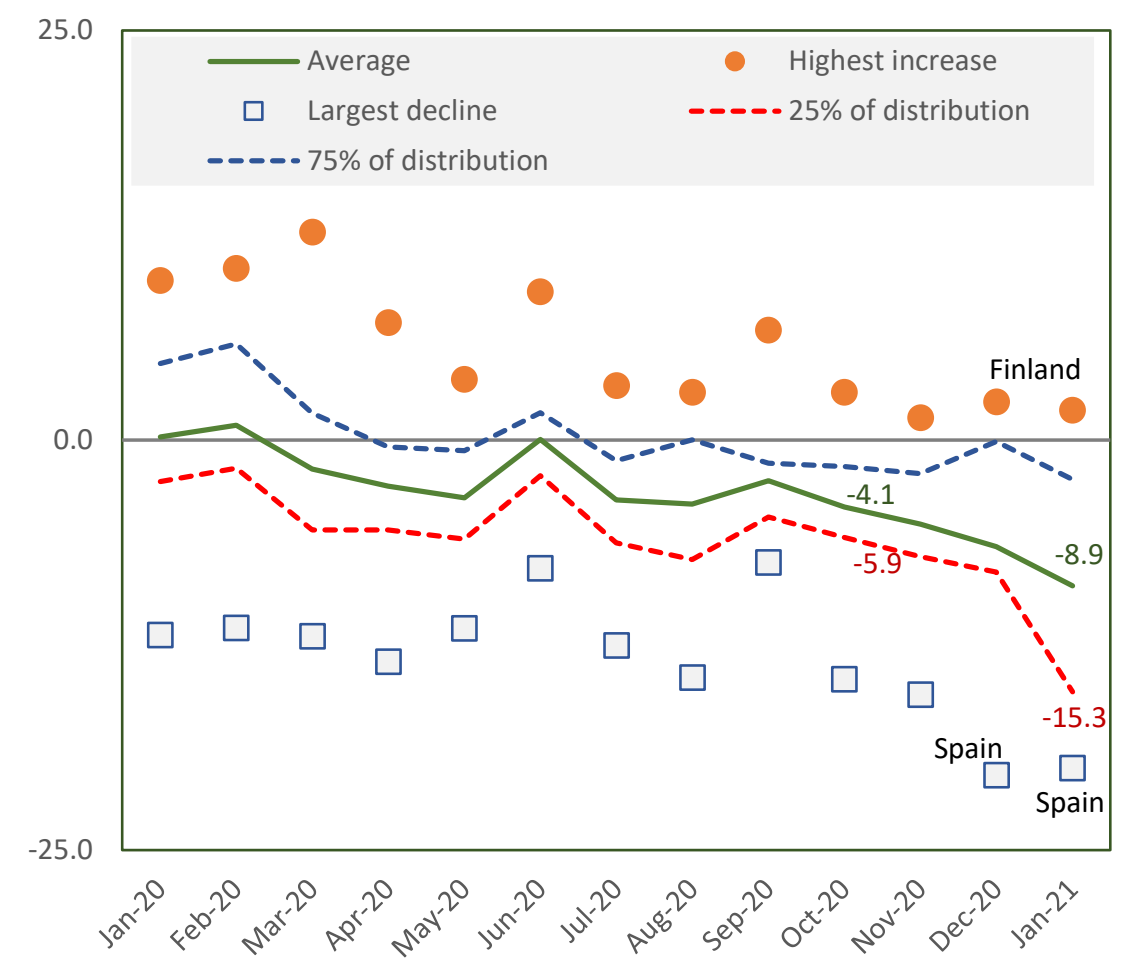

Note: The figure is based on data for all countries covered in this report except for five countries with unstable trends in births (and with the December 2020 peak) - Lithuania, Romania, Russia, Taiwan, and Ukraine. The data for January 2021 cover the following nine countries: Croatia, Estonia, Hungary, Finland, France, the Netherlands, Slovenia, Spain, and Sweden.

\subsection{Regional and cross-country differences}

Figure 15 summarizes changes in relative births in selected countries and regions. This is a preliminary evidence, based on limited data past December 2020. When findings for broader regions are considered, two main regional contrasts can be highlighted: Spain, the only country representing Southern Europe in this report, shows the sharpest fall in the number of births across the analysed countries and regions. By contrast, the Nordic countries display very limited changes in birth trends until now. In between these two contrasting patterns, Western Europe, United States, and Central Europe show an expected trend of accelerating birth declines. Russia displays an unstable (though declining) pattern, also typical for some other countries in Eastern and South-Eastern Europe. Table 1 provides a more nuanced summary of regional and country trends, categorising birth trends across all analysed countries into broader categories. This is a preliminary and simplified picture that will be revised as more recent data (and for more countries) become available. The table puts twelve countries, i.e., over a half of all analysed, into a category with discernible trend towards falling number of births past October 2020. Among them, eight display an acceleration of the previous decline in the number of births (United States, Taiwan, Belgium, France, Latvia, Russia, with further two countries, Spain and Estonia, showing a sharp downward drift), three countries show a shift from relatively stable to declining births (Austria, Croatia, Sweden) and Hungary displays a trend reversal from increasing to declining births. 
Seven countries display relatively stable trend past October 2020, either with relatively stable or slightly rising births (Denmark, Finland, the Netherlands, Norway), or with a longer-term trend of declining number of births established throughout 2020 (Bulgaria, Slovenia, South Korea). Finally, monthly births in three countries, Lithuania, Romania, and Ukraine, have been too unstable to discern a consistent trend.

Figure 15: Relative change (\%) in the number of births since January 2020 compared with the same month in the previous year, selected countries and averages for selected regions

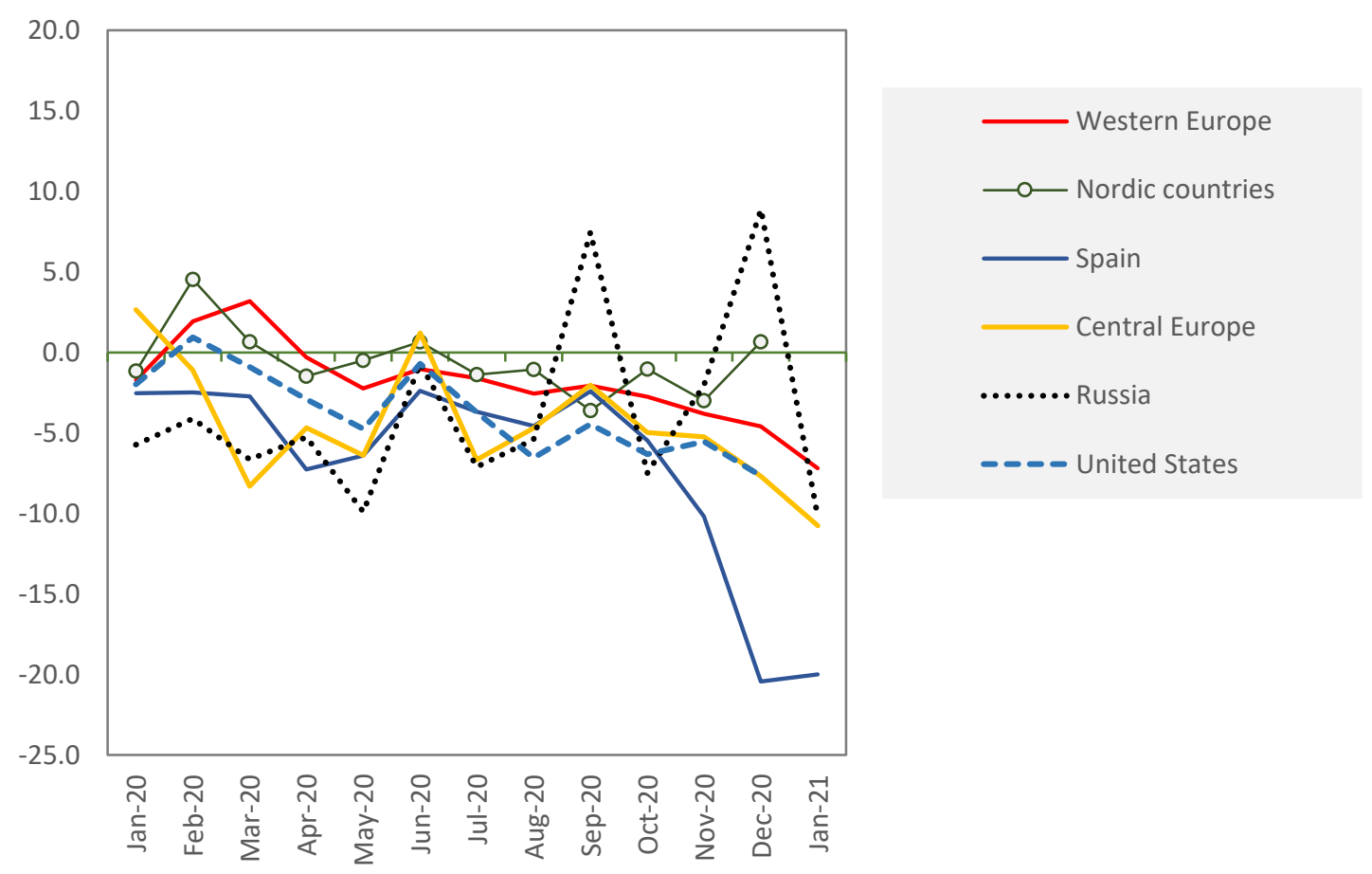

Note: See Appendix Table AP-1 for the list of countries by broader regions. Data for January 2021 are available for a smaller number of countries; see Table AP-1. 
Table 1: A stylised summary of trends in the number of births since October 2020 (data for countries marked in grey available until January or February 2021)

\begin{tabular}{|c|c|c|c|c|c|c|}
\hline $\begin{array}{l}\text { Declining tr } \\
\text { Trend } \\
\text { reversal: } \\
\text { increase to } \\
\text { decline }\end{array}$ & $\begin{array}{l}\text { d } \\
\text { Accelerated } \\
\text { decline: } \\
\text { sharp } \\
\text { downturn }\end{array}$ & $\begin{array}{l}\text { Accelerated } \\
\text { decline: } \\
\text { downturn }\end{array}$ & $\begin{array}{l}\text { Shift from } \\
\text { stable to } \\
\text { declining } \\
\text { births }\end{array}$ & $\begin{array}{l}\text { Stable trend } \\
\text { Stable trend: } \\
\text { no change or } \\
\text { slight } \\
\text { increase }\end{array}$ & $\begin{array}{l}\text { Stable trend: } \\
\text { declining } \\
\text { births }\end{array}$ & $\begin{array}{l}\text { Fluctuations, } \\
\text { no clear } \\
\text { trend }\end{array}$ \\
\hline $\begin{array}{l}\text { Central } \\
\text { Europe: }\end{array}$ & $\begin{array}{l}\text { Southern } \\
\text { Europe: }\end{array}$ & United States & $\begin{array}{l}\text { Western } \\
\text { Europe: }\end{array}$ & $\begin{array}{l}\text { Western } \\
\text { Europe: }\end{array}$ & East Asia: & $\begin{array}{l}\text { Central } \\
\text { Europe: }\end{array}$ \\
\hline \multirow[t]{7}{*}{ Hungary } & $\begin{array}{l}\text { Spain } \\
\text { Central } \\
\text { Europe: }\end{array}$ & East Asia: & $\begin{array}{l}\text { Austria } \\
\text { Nordic } \\
\text { countries }\end{array}$ & $\begin{array}{l}\text { Netherlands } \\
\text { Nordic } \\
\text { countries: }\end{array}$ & $\begin{array}{l}\text { South Korea } \\
\text { Central } \\
\text { Europe: }\end{array}$ & $\begin{array}{l}\text { Lithuania } \\
\text { Eastern } \\
\text { Europe: }\end{array}$ \\
\hline & Estonia & Western Europe: & Sweden & Denmark & Slovenia & Romania \\
\hline & & $\begin{array}{l}\text { Belgium } \\
\text { France }\end{array}$ & $\begin{array}{l}\text { Central } \\
\text { Europe: } \\
\text { Croatia }\end{array}$ & $\begin{array}{l}\text { Finland } \\
\text { Norway }\end{array}$ & $\begin{array}{l}\text { Eastern } \\
\text { Europe: } \\
\text { Bulgaria }\end{array}$ & Ukraine \\
\hline & & Central Europe & & & & \\
\hline & & Latvia & & & & \\
\hline & & Eastern Europe: & & & & \\
\hline & & Russia & & & & \\
\hline
\end{tabular}

\subsection{Latest evidence: trends in January 2021}

The analysis above revealed that a sharp downturn in the number of births is often observed only since January 2021. Therefore, we provide an additional analysis of birth trends in twelve countries, for which birth data are available for January 2021. When we select nine countries without December spike, the data reveal a shift towards a stronger year-on-year decline (over 10\%) in two countries in November-December 2020 and in four countries in January 2021 (Figure 16). Figure 17 ranks all twelve countries with available data by the pace of their birth decline in January 2021 compared with January 2020. This graph gives the clearest picture of the magnitude of recent birth declines: two countries display a decline of $20-25 \%$ (Spain and Taiwan), further six show a fall in births by $10 \%$ to $17 \%$ and only one, Finland, shows an increase in the number of births. The downward dynamics in birth trends is apparent when contrasting the latest birth trends in January 2021 with those in January-September 2020, still reflecting pre-pandemic conceptions: eight countries show a clear downward shift in birth trends and only four, Lithuania, Slovenia, the Netherlands, and Finland, show a similar birth dynamic in both periods. 
Figure 16: Monthly change in the number of births (\%) compared to the same month previous year in 9 countries, January 2020 to January 2021

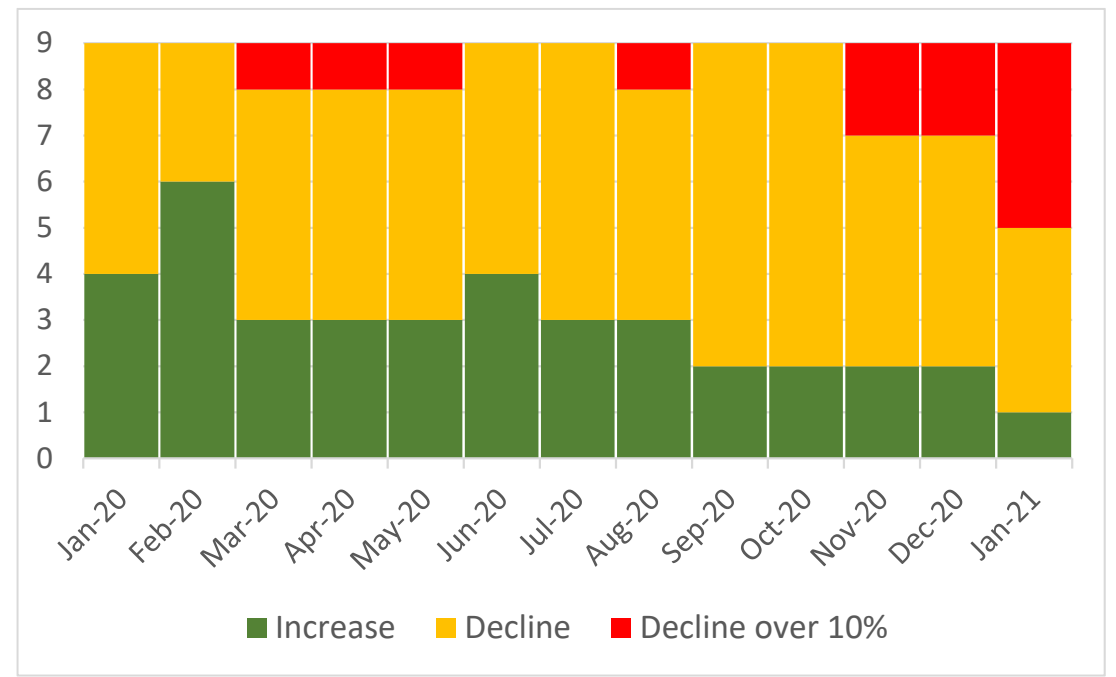

Note: the figure covers the following countries: Croatia, Estonia, France, Finland, Hungary, Netherlands, Slovenia, Spain, and Sweden

Figure 17: Relative change in the number of births in January 2021 and in January-September 2020, compared with the same period in the previous year, in \% (countries ranked by the pace of their birth decline in January 2021)

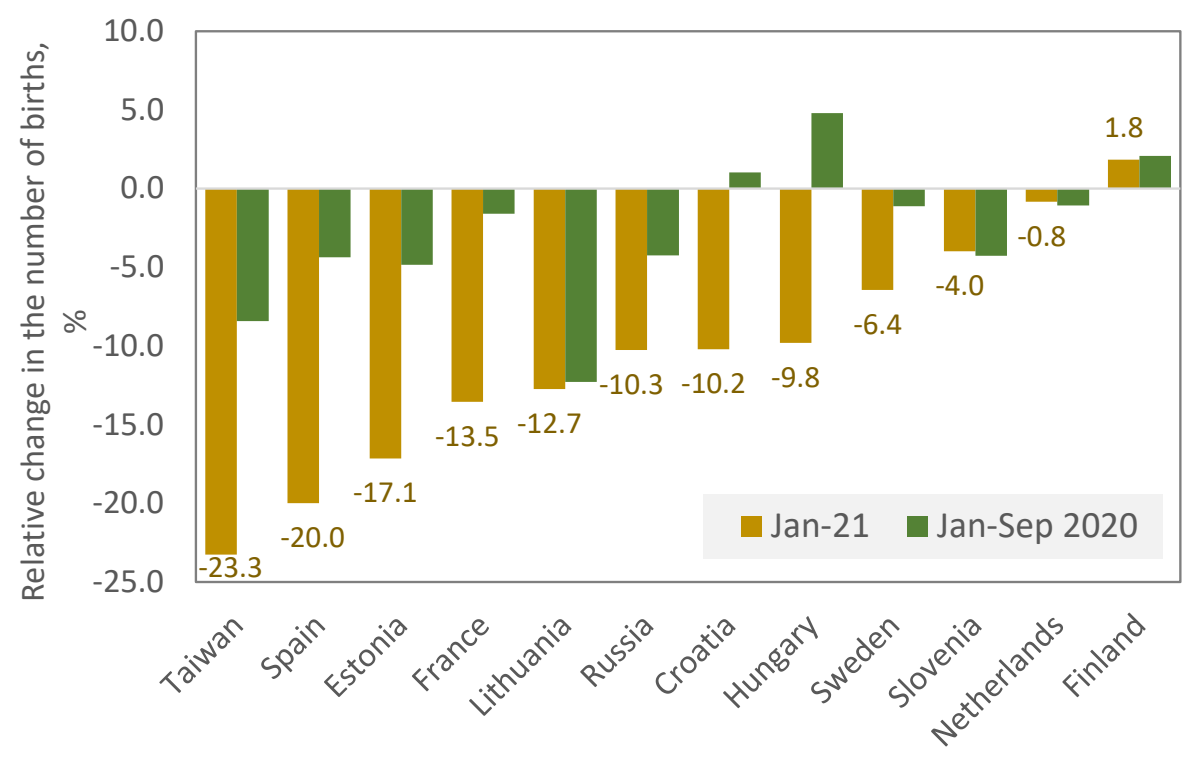

\section{Concluding discussion: falls in fertility rates will lead to population decline in many countries}

Broadly in line with the expected "birth recession" induced by the COVID-19 pandemic, monthly number of births (as compared with the same month in the previous year) in many countries fell sharply between October 2020 and the most recent month observed, often bringing about a clear reversal of the previous trend. Remarkably, there was no single country reporting a sustained increase in births in the analysed period, which suggests that some earlier media speculations and popular 
imagination about covid-driven baby boom were misplaced. In some countries, including Bulgaria, Netherlands, Finland, Norway, and Slovenia, birth trends remained flat in the wake of the pandemic. Our analysis is based on preliminary data and reflects the pregnancies started in the initial months of the pandemic. Therefore, we reiterate the often stated "mantra" that more data are needed to provide a more solid evidence on the emerging fertility downturns.

Most countries with available data for January 2021, reflecting pregnancies started in April and early May 2020, show a deepening baby bust. If the drop in the number of births suggested by the data for January 2021 prevails over the next months, many of the analysed countries will experience a fall in fertility rates to extreme low levels, often reaching the lowest level on record. A wider "return" of "lowest-low fertility" (a Total Fertility Rate at or below 1.3), which had been prevalent in many rich countries in the late 1990s and early 2000s (Goldstein et al. 2009) is likely across Europe and East Asia. Italy, Spain and Taiwan are likely to see their period Total Fertility Rate plunging to or below 1 . In the United States, the TFR may fall below 1.5, a record low, and in Russia it may drop to around 1.3.

The downturn in the number of births will also have a strong impact on short-term population trends. The combined effect of rising mortality and falling birth rates in the wake of the pandemic will disrupt the balance of births and deaths in many countries. Often, these effects are already visible in 2020 (Figure 18). As a result, some countries, including Austria and Belgium, saw their initially positive balance of births and deaths turn negative. Countries with initially higher fertility, like France and the United States, saw their positive natural population growth plummet in 2020. Finally, countries with a negative natural population balance, including Russia and Spain, saw the gap between the number of births and deaths widening further.

As the COVID-19 pandemic continued strongly affecting most of the highly developed countries, with the second wave hitting in October-December 2020, and as the new peaks in the reported cases were often reached in the first three months of 2021, the pandemic will cast a long shadow on birth trends throughout the whole year 2021 and probably beyond. This may push natural population increase to yet lower levels. In the next 35 years, economic and labour market uncertainty are likely to continue exerting negative pressure on fertility plans, even if the waves of infection eventually subside. This implies that different scenarios of post-pandemic fertility recovery (e.g., Goldstein 2020), especially of a rapid $V$-shaped baby boom, are unlikely to materialise soon. This is especially true in countries with weaker family policies, more disadvantaged position of young adults, higher gender inequalities, deeper economic recession and dysfunctional labour market, including Southern Europe and much of Eastern and South-Eastern Europe. 
Figure 18: Number of births and deaths and natural population increase in selected countries, 20182020
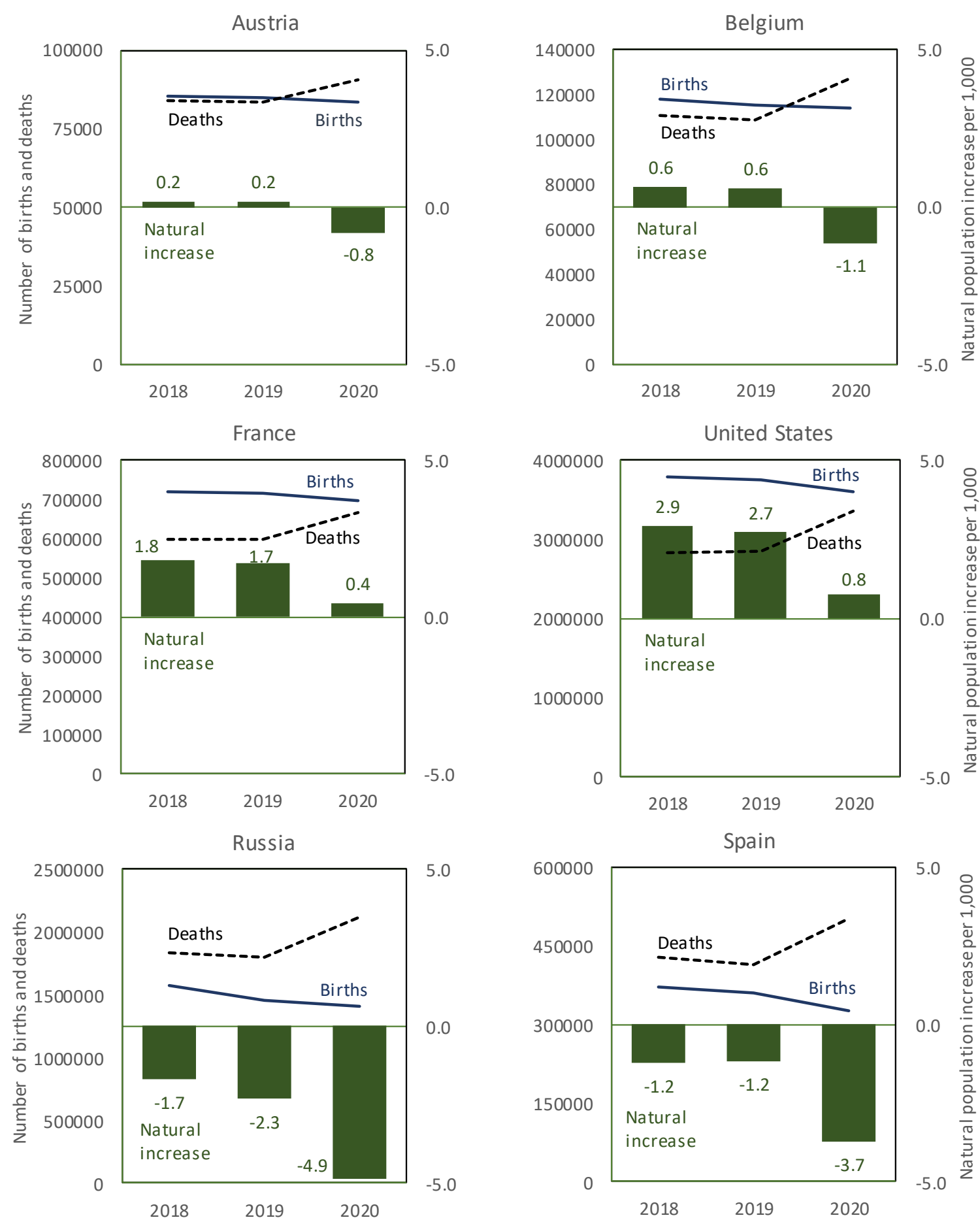

Source: Data on live births: Human Fertility Database 2021 (including STFF data); data on deaths: Human Mortality Database (STMF) 2021 (authors' elaboration of data), Eurostat (2021), and epdata (2021) for Spain; data on population size (used to compute natural population increase): Eurostat (2021). 


\section{References}

Aassve, A., Cavalli,N., Mencarini, L., Plach, S., and Bacci, M.L.. 2020. The COVID-19 pandemic and human fertility. Science 369(6502): 370-371. doi: 10.1126/science.abc9520

Adserà, A. 2011. Where are the babies? Labor market conditions and fertility in Europe. European Journal of Population 27(1): 1-32. doi: https://doi.org/10.1007/s10680-010-9222-x

Barbieri, P., Bozzon, R., Scherer, S., Grotti, R. and Lugo, M. 2015. The rise of a Latin model? Family and fertility consequences of employment instability in Italy and Spain. European Societies 17(4): 423-446. doi: https://doi.org/10.1080/14616696.2015.1064147

Beaujouan, É. 2021. Covid-19 Global Demographic Research Needs? Replacing Speculative Commentaries with Robust Cross-national Comparisons. In L. MacKellar and R. Friedman (eds.) Covid19 and the Global Demographic Research Agenda. New York: Population Council, pp. 8-14.

https://knowledgecommons.popcouncil.org/cgi/viewcontent.cgi?article=1002\&context=series pdr essays-covid

Blangiardo, G.C. 2021. "riscontri e riflessioni sul bilancio demografico del 2020. ISTAT, 1 February 2021. Accessed at https://www.istat.it/it/files/2020/04/Riscontri-e-Riflessioni Bilancio-demografico2020.pdf

Cohen, Philip N. 2021. Pandemic baby bust situation update. Family Inequality blog, accessed 13 March 2021 (last update 29 January 2021).

https://familyinequality.wordpress.com/2021/01/29/pandemic-baby-bust-situation-update

Comolli, C, L. 2017. The fertility response to the Great Recession in Europe and the United States: Structural economic conditions and perceived economic uncertainty. Demographic Research 36(51): 1549-1600. doi: 10.4054/DemRes.2017.36.51

Comolli, C.L. and Vignoli, D., 2021. Spreading uncertainty, shrinking birth rates: a natural experiment for Italy. European Sociological Review. doi: https://doi.org/10.1093/esr/icab001

Dahlberg, J. and Andersson, G., 2019. Fecundity and human birth seasonality in Sweden: a registerbased study. Reproductive Health, 16(1): 1-8. doi: 10.1186/s12978-019-0754-1

epdata. 2021. Mortalidad estimada y registrada por cualquier causa coincidiendo con la epidemia del coronavirus. Data on deaths and mortality in Spain in 2020 accessed at https://www.epdata.es/datos/mortalidad-estimada-registrada-cualquier-causa-coincidiendoepidemia-coronavirus/521/espana/106 (accessed 12 March 2021, last update 11 March 2021).

Eurostat. 2021. Data on deaths by week in 2020 (table demo_r_mwk_ts) and data on population (table DEMO_GIND) in selected European countries. Accessed in March 2021 at https://ec.europa.eu/eurostat/data/database

Goldstein, J. R., T. Sobotka, and A. Jasilioniene. 2009. The end of lowest-low fertility? Population and Development Review 35(4): 663-700. https://doi.org/10.1111/j.1728-4457.2009.00304.x

Goldstein, Joshua R. 2020. Rebirth after disaster: models of post-pandemic fertility and marriage. Keynote, conference on "Demographic aspects of the COVID-19 pandemic and its consequences," Vienna, Wittgenstein Centre for Demography and Global Human Capital, 30 November 2020. https://www.oeaw.ac.at/fileadmin/subsites/Institute/VID/PDF/Conferences/2020/COVID19/Slides/K eynote 2 Goldstein WIC2020.pdf

Human Fertility Database. 2021. Short-Term Fertility Fluctuations (STFF) data series. Max Planck Institute for Demographic Research (Germany) and Vienna Institute of Demography (Wittgenstein 
Centre, Austria). Available at https://www.humanfertility.org/cgi-bin/stff.php (accessed 13 March 2021).

Human Mortality Database. 2021. Short-term Mortality Fluctuations (STMF) data series. University of California, Berkeley (USA), and Max Planck Institute for Demographic Research (Germany). Accessed 12 March 2021 at https://www.mortality.org

Jukic, A.M., Baird, D.D., Weinberg, C.R., McConnaughey, D.R. and Wilcox, A.J. 2013. Length of human pregnancy and contributors to its natural variation. Human Reproduction, 28(10): 2848-2855. doi: https://doi.org/10.1093/humrep/det297

Kearney, Melissa S. and Phillip B. and Levine. 2020a. Half a million fewer children? The coming COVID baby bust. Report, Brookings. Accessed 14 March 2021 at https://www. brookings.edu/research/halfa-million-fewer-children-the-coming-covid-baby-bust

Kearney, Melissa S. and Phillip B. and Levine. 2020b. The coming COVID-19 baby bust: Update. Brookings. Accessed 8 March 2021 at https://www.brookings.edu/blog/up-front/2020/12/17/thecoming-covid-19-baby-bust-update

Lehmiller, J.J., J.R. Garcia, A.N. Gesselman and K.P. Mark. 2020. Less sex, but more sexual diversity: changes in sexual behavior during the COVID-19 coronavirus pandemic. Leisure Sciences, doi: $\underline{10.1080 / 01490400.2020 .1774016}$

Lindberg, L.D., A. VandeVusse, J. Mueller and M. Kirstein. 2020. Early impacts of the COVID-19 pandemic: Findings from the 2020 Guttmacher survey of reproductive health experiences. New York: Guttmacher Institute, 24 June 2020. https://www.guttmacher.org/report/early-impacts-covid-19pandemic-findings-2020-guttmacher-survey-reproductive-health

Luppi, F., Arpino, B. and Rosina, A., 2020. The impact of COVID-19 on fertility plans in Italy, Germany, France, Spain, and the United Kingdom. Demographic Research, 43: 1399-1412. doi: 10.4054/DemRes.2020.43.47

Makay, Zsuzsanna. 2019. The family support system and female employment. Chapter 5 in J.

Monostori, P. Őri, and Z. Spéder (eds.). Demographic Portrait of Hungary 2018. Budapest: Hungarian Demographic Research Institute.

https://www.demografia.hu/en/publicationsonline/index.php/demographicportrait/article/view/953 $\not 725$

Marteleto, L.J., Guedes, G., Coutinho, R.Z. and Weitzman, A. 2020. Live births and fertility amid the Zika epidemic in Brazil. Demography, 57: 843-872; https://doi.org/10.1007/s13524-020-00871-x

Pinsker, J. 2020. Here comes the COVID-19 baby bust. The Atlantic, November 24, 2020.

https://www.theatlantic.com/family/archive/2020/11/covid-19-pandemic-births-baby-bust/617149

Rangel, M.A., Nobles, J. and Hamoudi, A., 2020. Brazil's missing infants: Zika risk changes

reproductive behavior. Demography, 57(5): 1647-1680. https://doi.org/10.1007/s13524-020-00900-9

Régnier-Loilier, A. and Divinagracia, E. 2010. Changes in the seasonality of births in France from 1975 to the present. Population 65(1): 145-185.

Rosstat. 2021. Natural movement of population among the subjects of the Russian Federation, January-December 2020 (in Russian). Moscow: Federal State Statistics Service. Data accessed on 9 March 2021 at https://rosstat.gov.ru/storage/mediabank/TwbjcizH/edn12-2020.html

Ryall, Julian. 2020. 'Fear and finances': births in Japan predicted to fall below this year's record low over coronavirus concerns. South China Morning Post, 29 December 2020. 
https://www.scmp.com/week-asia/health-environment/article/3115688/fear-and-finances-birthsjapan-predicted-fall-below

Settersten, R.A., L. Bernardi, J. Härkönen, T.C. Antonucci, P.A. Dykstra, J. Heckhausen, D. Kuh, K.U. Mayer, P. Moen, J.T. Mortimer, C.H. Mulder, T.M. Smeeding, T. van der Lippe, G.O. Hagestad, M. Kohli, R. Levy, I. Schoon and E. Thomson. 2020. Understanding the effects of Covid-19 through a life course lens. Advances in Life Course Research 45 (September 2020).

https://doi.org/10.1016/i.alcr.2020.100360

Sobotka, T., V. Skirbekk, and D. Philipov. 2011. Economic recession and fertility in the developed world. Population and Development Review 37(2): 267-306. https://doi.org/10.1111/i.17284457.2011.00411.x

Statistics Korea. 2021. KOSIS Database, vital statistics data for 2019-2020. Accessed 5 March 201 at https://kosis.kr/statHtml/statHtml.do?orgld=101\&tblld=DT 1B8000F\&conn path=I2\&language=en

Vignoli, D., Guetto, R., Bazzani, G., Pirani, E. and Minello, A., 2020. A reflection on economic uncertainty and fertility in Europe: The Narrative Framework. Genus, 76(1): 1-27.

https://doi.org/10.1186/s41118-020-00094-3

Wilde, J., Chen, W. and Lohmann, S., 2020. COVID-19 and the future of US fertility: what can we learn from Google? IZA Discussion Papers, No. 13776. https://www.iza.org/publications/dp/13776/covid19-and-the-future-of-us-fertility-what-can-we-learn-from-google 
Baby bust in the wake of the COVID-19 pandemic? First results from the new STFF data series

\section{Supplementary Appendix}

Tomáš Sobotka ${ }^{1}$, Aiva Jasilioniene², Ainhoa Alustiza Galarza², Kryštof Zeman ${ }^{3}$, László Németh², and Dmitri Jdanov ${ }^{2}$

\section{Version 24 March 2021}

Authors' affiliation:

${ }^{1}$ Vienna Institute of Demography (Austrian Academy of Sciences (OeAW)), Wittgenstein Centre for Demography and Global Human Capital (IIASA, OeAW, University of Vienna), Vienna, Austria; email: tomas.sobotka@oeaw.ac.at

${ }^{2}$ Max Planck Institute for Demographic Research (MPIDR), Rostock (Germany)

${ }^{3}$ University of Vienna, Wittgenstein Centre for Demography and Global Human Capital (IIASA, OeAW, University of Vienna), Vienna, Austria 
APPENDIX 1: STFF data series: countries covered in this report and countries that are not included STFF Data covered in this report

\begin{tabular}{|c|c|c|c|}
\hline Country / area & $\begin{array}{l}\text { Country } \\
\text { code }\end{array}$ & Data source & $\begin{array}{c}\text { Most recent data } \\
\text { available (Month_Year) }\end{array}$ \\
\hline Austria & AUT & Statistik Austria & 12_2020 \\
\hline Belgium & BEL & $\begin{array}{l}\text { Belgian Statistical Office, STATBEL } \\
\text { National Statistical Institute of Bulgaria / }\end{array}$ & 12_2020 \\
\hline Bulgaria & BRG & Eurostat & $12 \_2020$ \\
\hline Denmark & DNK & Statistics Denmark & 12_2020 \\
\hline Spain & ESP & National Statistics Institute, INE & 01_2021 \\
\hline Estonia & EST & Statistics Estonia & 01_2021 \\
\hline Finland & FIN & $\begin{array}{l}\text { Statistics Finland } \\
\text { Institut National de la Statistique et des Études }\end{array}$ & 01_2021 \\
\hline France & FRATNP & Économiques, INSEE & 01_2021 \\
\hline Croatia & HRV & Croatian Bureau of Statistics & 01_2021 \\
\hline $\begin{array}{l}\text { Hungary } \\
\text { Republic of }\end{array}$ & HUN & Hungarian Central Statistical Office & 01_2021 \\
\hline Korea & KOR & Statistics Korea & $12 \_2020$ \\
\hline Lithuania & LTU & Statistics Lithuania & 02_2021 \\
\hline Latvia & LVA & Central Statistical Bureau of Latvia & $12 \_2020$ \\
\hline Netherlands & NLD & Centraal Bureau voor de Statistiek Netherlands & 01_2021 \\
\hline Norway & NOR & $\begin{array}{l}\text { Statistics Norway } \\
\text { National Institute of Statistics of Romania / }\end{array}$ & $12 \_2020$ \\
\hline Romania & ROU & Eurostat & $12 \_2020$ \\
\hline Russia & RUS & Federal State Statistics Service of Russia, Rosstat & 01_2021 \\
\hline Slovenia & SVN & Statistical Office of the Republic of Slovenia & 01_2021 \\
\hline Sweden & SWE & $\begin{array}{l}\text { Statistics Sweden, SCB } \\
\text { Dept. of Household Registration Affairs, Ministry }\end{array}$ & 01_2021 \\
\hline Taiwan & TWN & of the Interior, MOI. & 02_2021 \\
\hline Ukraine & UKR & State Statistics Service of Ukraine, Ukrstat & $12 \_2020$ \\
\hline United States & USA & Centers for Disease Control and Prevention, CDC & 12_2020 \\
\hline
\end{tabular}

STFF data not covered in this report

\begin{tabular}{|c|c|c|c|}
\hline Country / area & $\begin{array}{l}\text { Country } \\
\text { code }\end{array}$ & Data source & $\begin{array}{c}\text { Most recent data } \\
\text { available (Month_Year) }\end{array}$ \\
\hline Switzerland & $\mathrm{CHE}$ & Swiss Federal Statistical Office & 11_2020 \\
\hline Chile & $\mathrm{CHL}$ & Ministerio de Salud, MINSAL & 11_2020 \\
\hline Czechia & CZE & Czech Statistical Office & 09_2020 \\
\hline $\begin{array}{l}\text { Germany } \\
\text { UK: England \& }\end{array}$ & DEU & Statistisches Bundesamt Deutschland, DESTATIS & 11_2020 \\
\hline Wales & GBRENW & Office for National Statistics, ONS & 09_2020 \\
\hline Israel & ISR & Central Bureau of Statistics of Israel & 11_2020 \\
\hline Italy & ITA & Istituto Nazionale di Statistica, Istat & 11_2020 \\
\hline Japan & JPN & Ministry of Health, Labour and Welfare & 10_2020 \\
\hline New Zealand & NZL & Statistics New Zealand & 06_2020 \\
\hline Portugal & PRT & Statistics Portugal & 102020 \\
\hline
\end{tabular}


Figure AP-1: Relative change in the reported number of births (in \%) compared to the same month in the previous year, selected countries with fluctuating data, January 2020 to January 2021

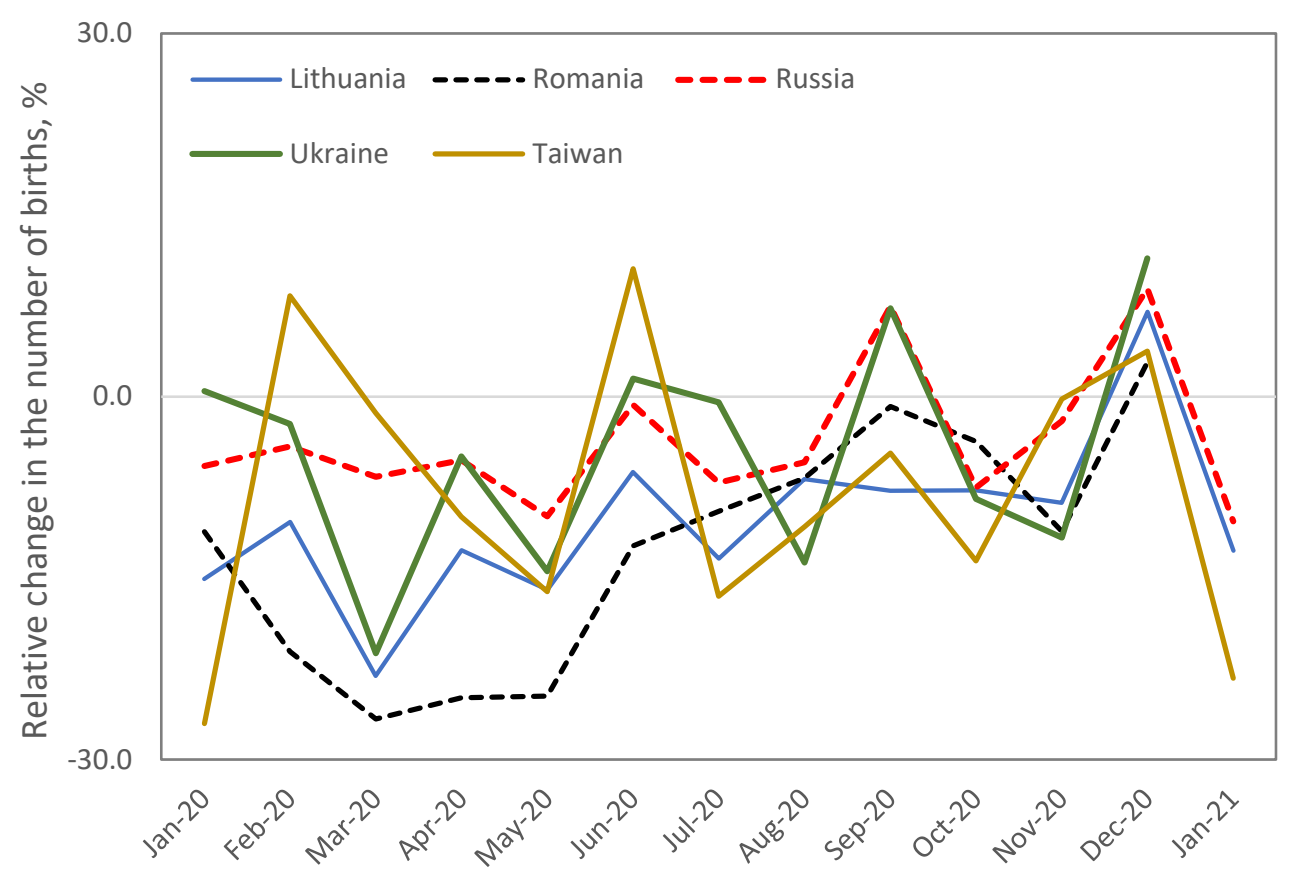


Figure AP-2: Trends in the number of births by month in 2020 and relative change in the number of births compared to the same month in 2019 , selected regions and countries

\section{East Asia: South Korea}

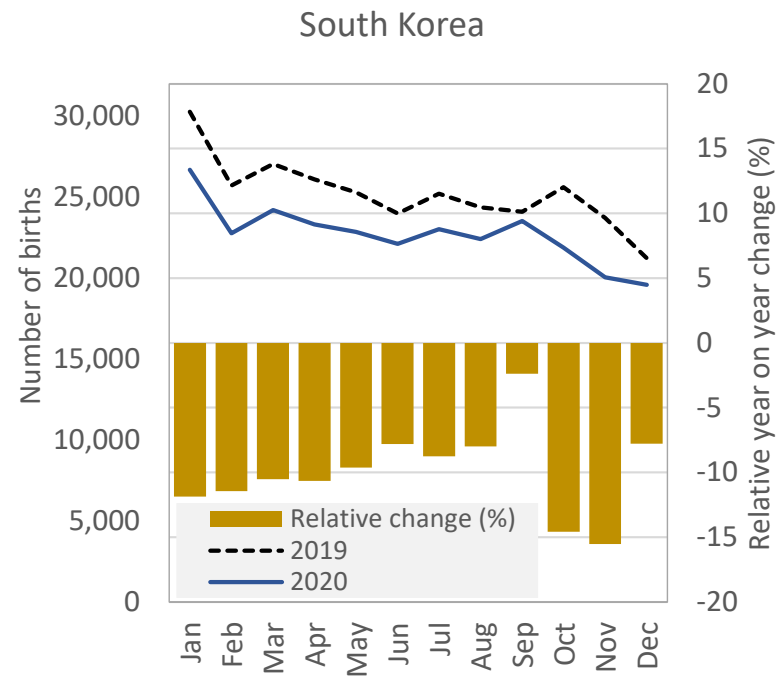

Nordic countries: Denmark and Norway
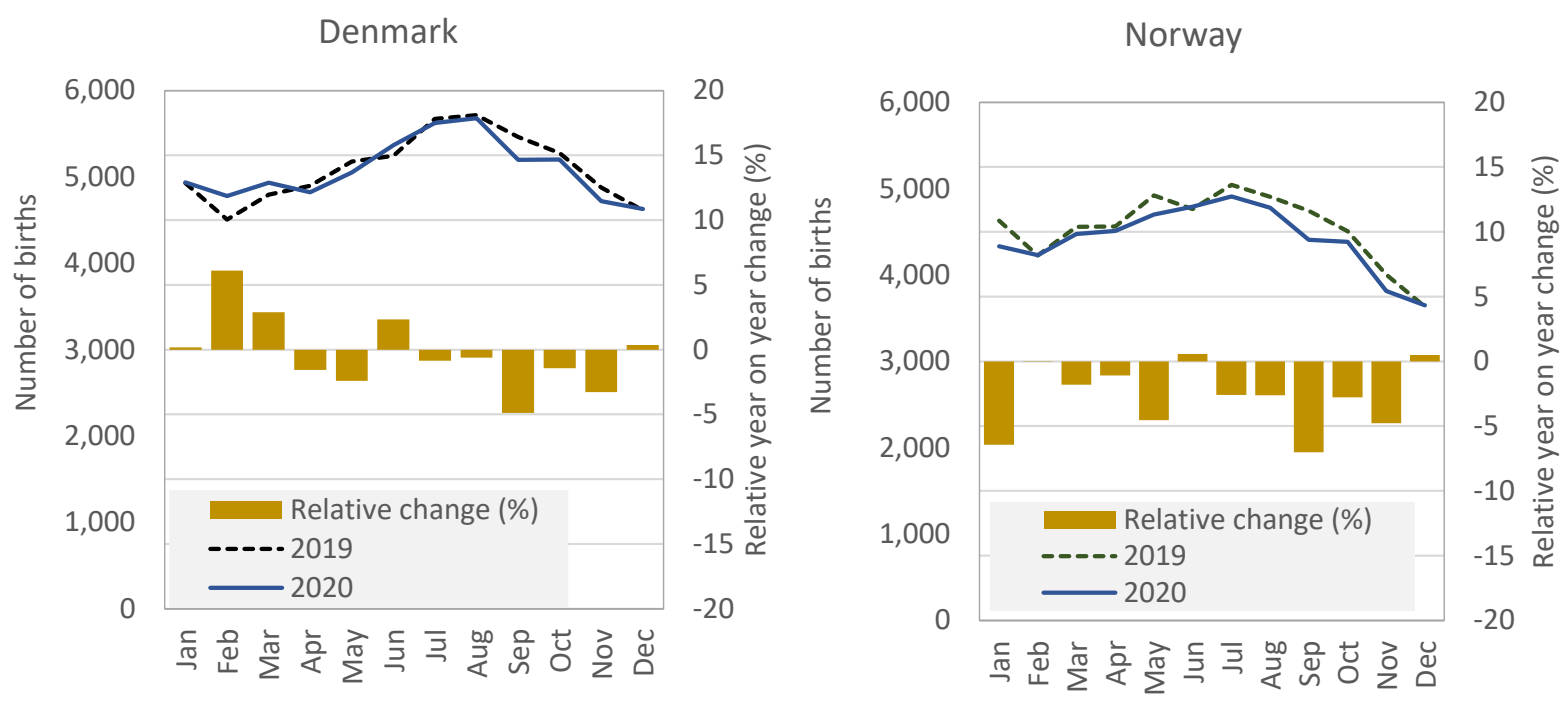


\section{Central Europe: Latvia}

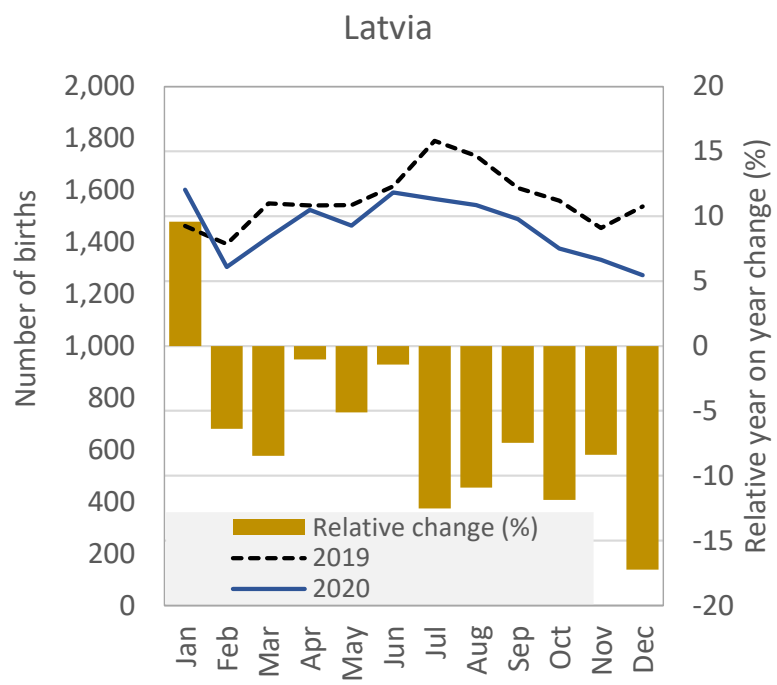

\section{Eastern and South-Eastern Europe: Bulgaria and Romania}
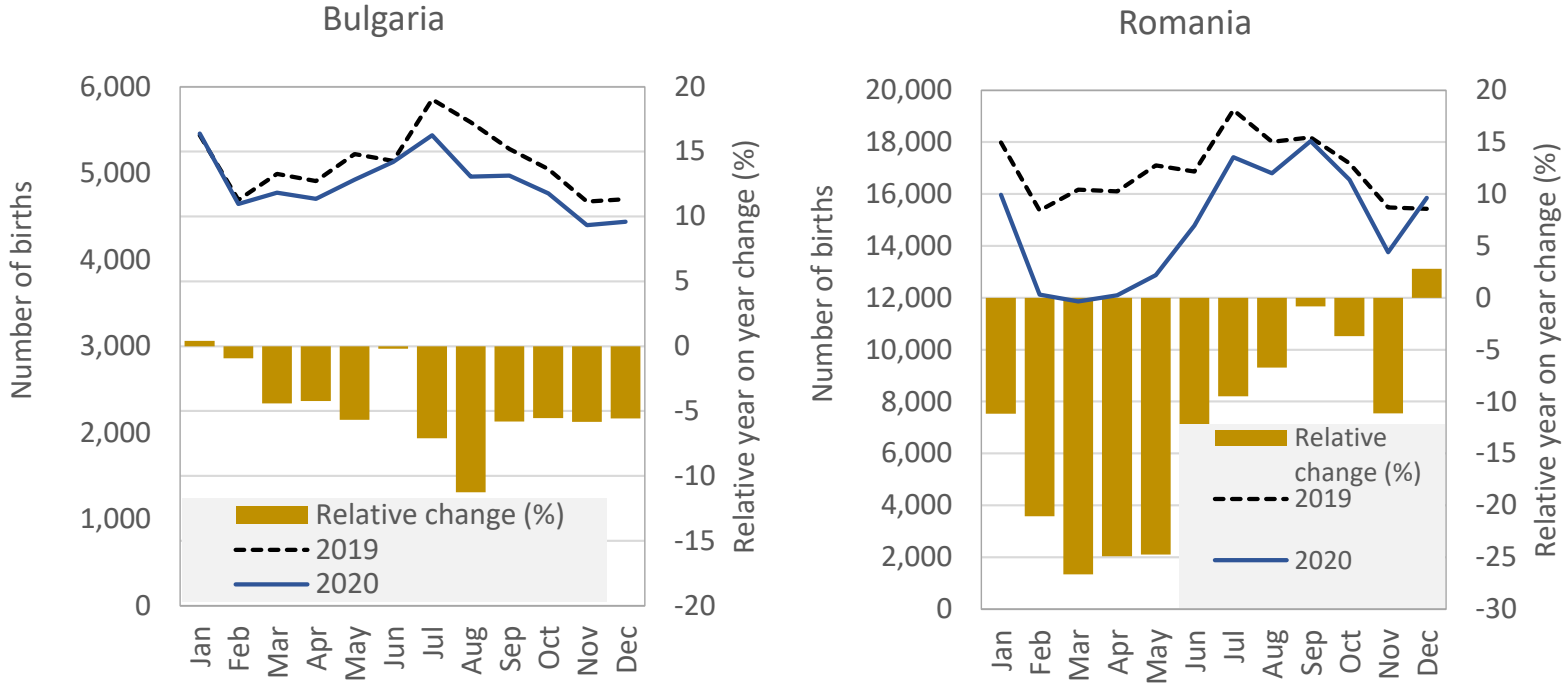
Figure AP-3: Recent trends in the number of births by month, relative change in the number of births compared to the same period in the preceding year, selected regions and countries

\section{Western Europe: Austria and the Netherlands}

Austria

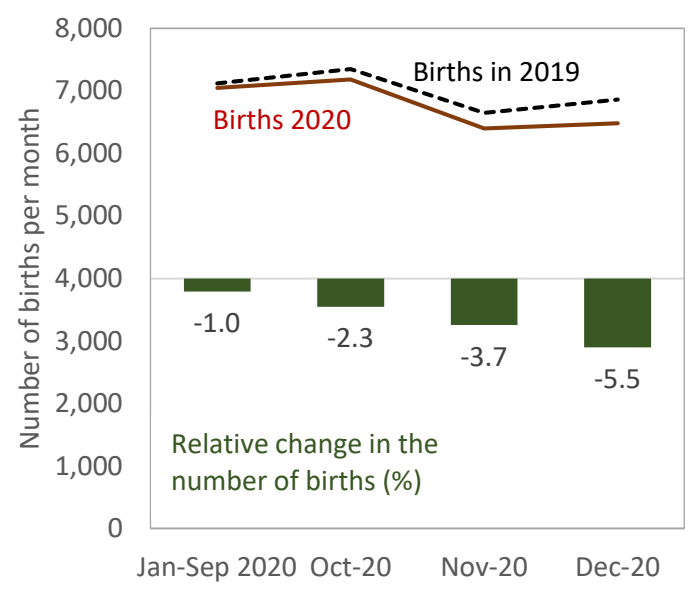

20

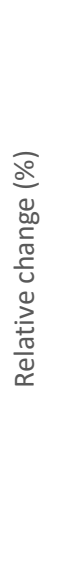

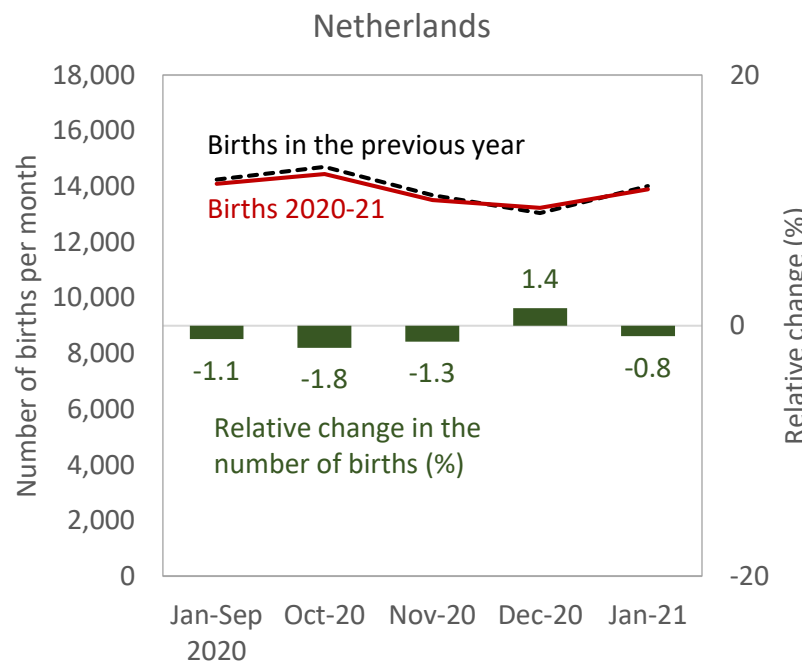

\section{Central Europe: Croatia and Slovenia}

Croatia

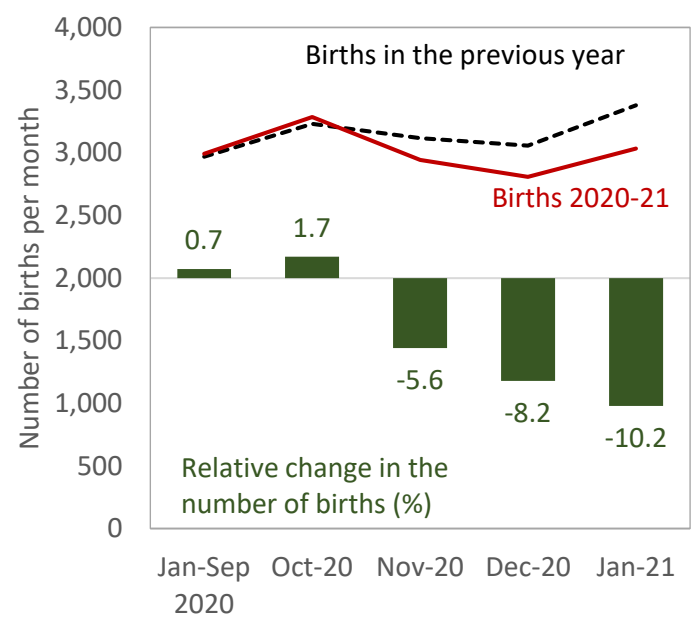

20



Slovenia

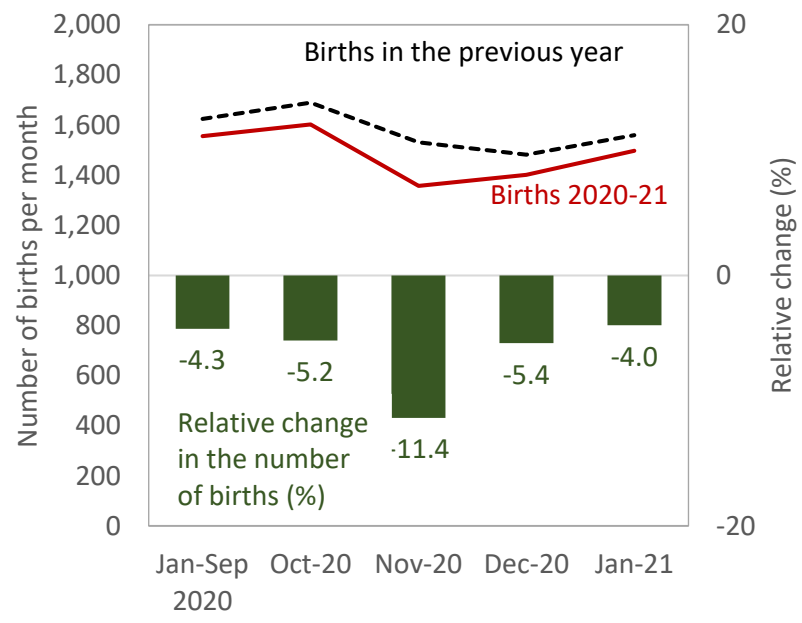


Table AP-1: Relative change in the number of births compared to the same period in the previous year in the analysed countries, and in Italy and Switzerland, January 2020 to February 2021

\begin{tabular}{|c|c|c|c|c|c|c|c|c|c|c|c|c|c|c|}
\hline & \multicolumn{12}{|c|}{2020} & \multicolumn{2}{|c|}{2021} \\
\hline & Jan & Feb & Mar & Apr & May & Jun & Jul & Aug & Sep & Oct & Nov & Dec & Jan & Feb \\
\hline \multicolumn{15}{|l|}{ East Asia } \\
\hline South Korea & -11.9 & -11.4 & -10.5 & -10.7 & -9.6 & -7.8 & -8.7 & -8.0 & -2.4 & -14.6 & -15.5 & -7.8 & & \\
\hline Taiwan & -27.0 & 8.3 & -1.4 & -9.9 & -16.1 & 10.6 & -16.5 & -10.8 & -4.7 & -13.6 & -0.2 & 3.7 & -23.3 & -15.1 \\
\hline United States & -2.0 & 0.9 & -0.9 & -2.9 & -4.8 & -0.7 & -3.7 & -6.5 & -4.5 & -6.3 & -5.5 & -7.7 & & \\
\hline \multicolumn{15}{|l|}{ Western Europe } \\
\hline Austria & -1.8 & -0.6 & -0.9 & -3.2 & 0.6 & -0.3 & -1.6 & 0.6 & -2.1 & -2.3 & -3.7 & -5.5 & & \\
\hline Belgium & -2.5 & -0.8 & 12.7 & 7.2 & -2.9 & 0.5 & -2.4 & -4.3 & -1.9 & -4.3 & -5.8 & -7.0 & & \\
\hline France & -1.3 & 3.2 & 1.3 & -2.2 & -2.3 & -2.0 & -3.1 & -4.1 & -2.8 & -2.8 & -4.4 & -7.2 & -13.5 & \\
\hline Netherlands & -1.2 & 5.9 & -0.4 & -2.9 & -4.3 & -2.4 & 0.6 & -2.4 & -1.4 & -1.8 & -1.3 & 1.4 & -0.8 & \\
\hline Switzerland & -7.2 & -1.5 & -6.5 & -8.1 & -7.8 & -6.3 & -7.7 & -8.2 & -6.8 & -6.6 & -13.8 & & & \\
\hline \multicolumn{15}{|l|}{ Nordic countries } \\
\hline Denmark & 0.2 & 6.1 & 2.9 & -1.6 & -2.4 & 2.3 & -0.9 & -0.6 & -4.9 & -1.4 & -3.3 & 0.3 & & \\
\hline Finland & 1.0 & 10.5 & 3.2 & 0.2 & 3.7 & 1.0 & 1.4 & 1.7 & -2.4 & 1.9 & -1.2 & 2.3 & 1.8 & \\
\hline Norway & -6.4 & 0.0 & -1.8 & -1.1 & -4.5 & 0.6 & -2.6 & -2.6 & -7.0 & -2.8 & -4.8 & 0.5 & & \\
\hline Sweden & 0.6 & 1.5 & -1.7 & -3.5 & 1.3 & -1.4 & -3.4 & -2.8 & -0.2 & -1.9 & -2.8 & -0.5 & -6.4 & \\
\hline $\begin{array}{l}\text { Southern Europe } \\
\text { Italy }\end{array}$ & Southern Europe & 4.5 & -3.9 & -4.5 & -5.3 & -1.7 & -2.8 & -2.7 & -2.2 & -4.8 & -8.0 & & & \\
\hline Spain & -3.0 & -3.0 & -3.2 & -7.7 & -6.9 & -3.0 & -4.2 & -5.1 & -2.9 & -6.0 & -10.6 & -20.4 & -20.0 & \\
\hline \multicolumn{15}{|l|}{ Central Europe } \\
\hline Croatia & 8.3 & 5.8 & -12.0 & 3.5 & -1.9 & 5.0 & -4.5 & 2.9 & -0.4 & 1.7 & -5.6 & -8.2 & -10.2 & \\
\hline Estonia & 9.1 & -3.4 & -1.9 & -13.5 & -11.5 & 4.8 & -7.5 & -14.5 & -1.4 & -9.6 & 1.4 & -14.5 & -17.1 & \\
\hline Hungary & 9.7 & 7.8 & 2.0 & 2.4 & 2.5 & 9.1 & 3.3 & 1.9 & 6.7 & 2.9 & 1.3 & -7.9 & -9.8 & \\
\hline Latvia & 9.6 & -6.4 & -8.5 & -1.0 & -5.1 & -1.4 & -12.5 & -10.9 & -7.5 & -11.9 & -8.4 & -17.2 & & \\
\hline Lithuania & -15.1 & -10.4 & -23.1 & -12.7 & -16.0 & -6.2 & -13.4 & -6.8 & -7.8 & -7.8 & -8.8 & 7.0 & -12.7 & -10.2 \\
\hline Slovenia & -5.8 & -0.1 & -6.6 & -6.7 & -6.5 & -4.0 & -5.4 & -0.8 & -1.9 & -5.2 & -11.4 & -5.4 & -4.0 & \\
\hline \multicolumn{15}{|c|}{ Eastern and South-Eastern Europe } \\
\hline Bulgaria & 0.4 & -0.9 & -4.4 & -4.2 & -5.7 & -0.2 & -7.1 & -11.3 & -5.8 & -5.5 & -5.8 & -5.6 & & \\
\hline Romania & -11.2 & -21.1 & -26.6 & -24.9 & -24.7 & -12.3 & -9.5 & -6.7 & -0.8 & -3.7 & -11.1 & 2.8 & & \\
\hline Russia & -5.7 & -4.1 & -6.6 & -5.3 & -9.9 & -0.7 & -7.1 & -5.4 & 7.4 & -7.5 & -2.0 & 8.9 & -10.3 & \\
\hline Ukraine & 0.5 & -2.3 & -21.2 & -4.9 & -14.4 & 1.5 & -0.5 & -13.7 & 7.3 & -8.5 & -11.7 & 11.4 & & \\
\hline
\end{tabular}

